\title{
Serviço doméstico e habitus senhorial: considerações sobre a regulamentação do trabalho doméstico em Fortaleza (1880 - 1888)
}

\author{
Eylo Fagner Silva Rodrigues* \\ Universidade Federal do Ceará \\ Fortaleza - Ceará - Brasil
}

\section{Resuino}

Este artigo trata do contexto histórico da regulamentação do serviço doméstico em Fortaleza, capital cearense, entre 1881 e 1887; e busca dar a ver quais os interesses em torno do estabelecimento de Código de Posturas para a alocação de criados de servir e amas de leite. A partir de análises de discursos em periódicos coevos e do exame de fontes como o Livro de Matrícula de Criados de Servir de 1887, produzido no âmbito da Secretaria de Polícia, bem como do de outras fontes policiais, a exemplo dos ofícios da Chefatura de Polícia remetidos à presidência da Província, pode-se situar, no contexto da abolição dos escravos no Ceará, haja vista a ação de traficantes de escravos durante a seca de 1877-79, as medidas de regulação do serviço doméstico, a fim de envidar controle social sobre uma parcela dos pobres daquela cidade.

\section{Palaviras-chave}

Escravidão; Criados; Trabalho.

* Mestre e Doutorando no Programa de Pós-graduação em História Social da Universidade Federal do Ceará (UFC), Bolsista da CAPES (até março de 2017). E-mail: eylofagner@gmail.com. 


\section{Domestic service and manor house's habitus: considerations on the regulation of domestic work in Fortaleza (1880-1888)}

\section{Eylo Fagner Silva Rodrigues}

This article discusses the historical context of the regulation of domestic service in Fortaleza, capital of Ceará, between 1881 and 1887; and seeks to show which interests around the establishment of the Code of Postures for allocation of servants and wet nurses. From analyzes of speeches in contemporary newspapers and examination of sources such as the Book of registration of servants of 1887, produced in the frameworw of the Police Secretary, as well as of other police sources, as an example of the letters of the Police Chieftancy sent to the presidency of the Province, may be situated in the context of the abolition of slaves in Ceará, due to the action of traffickers of slaves during the drought of 1877-79, measures to regulate domestic service, in order to make social control in part of the poor of that city.

Slavery; Servants; Work. 
Passada a grande seca de 1877-79, período em que houve um acirramento do tráfico de escravos do Ceará para áreas de plantation, começaram a surgir sociedades abolicionistas, muito embora inúmeras famílias ainda se apegassem à propriedade servil. Os anos de seca estimularam o comércio de mão de obra cativa e o movimento de retirantes que seriam utilizados para trabalho compulsório em obras públicas, dentro de uma perspectiva modernizadora da província. Nesse contexto, fora apreciado na Câmara da capital cearense um projeto que visava a regulamentação da alocação de criado(a)s e amas de leite. Essa instituição era então presidida por Joaquim da Cunha Freire, barão de Ibiapaba, que também presidia a Junta Classificadora de escravos de Fortaleza. Tratava-se de um grande traficante de escravos do norte do Império e comerciante que, ao longo da década de 1870, usou a estrutura administrativa provincial, como presidente e vice-presidente interino em várias oportunidades, para viabilizar seus negócios no comércio negreiro e em outras atividades comerciais.

O projeto submetido ao plenário da Câmara de Fortaleza, em 1881, e composto de 32 artigos, não foi aprovado. Contudo, serviu de base para a redação de novo projeto de regulamentação do serviço doméstico apresentado à Câmara em 1887, três anos após a abolição oficial da escravidão naquela província. Por seis anos, no interregno entre a votação de um Código de Posturas para o serviço doméstico em 1881 até a efetiva aprovação de um projeto, nesse mesmo sentido, em 1887, as elites dominantes detiveram-se sobre a possibilidade de concretizar um mecanismo de controle dos pobres no mundo do trabalho que se articulou com demais medidas repressivas e disciplinadoras da experiência destes na cidade. A disciplina e o controle far-se-iam pela coerção ao trabalho, inclusive o doméstico, que, apesar de não produtivo, reproduziria o habitus senhorial, que, de acordo com Pierre Bourdieu, é espécie de senso de jogo, um conhecimento prático histo- 
ricamente assimilado, inscrito no corpo, para agir em certo espaço e situação cotidiana de modo racional, objetivo e deliberado. ${ }^{1}$

Até a assistência aos retirantes que buscavam o litoral na época de seca passou a se dar sob o signo do trabalho e da exploração da mão de obra compulsória de pessoas famintas. Uma parte dessas pessoas, principalmente mulheres viúvas ou abandonadas pelos cônjuges e órfãos, mas também inválidos anciões, que não retornaram ao interior do Ceará com o fim da seca de 1877-79, permaneceram nos arrabaldes de Fortaleza. Cultivavam e criavam o que comiam e vendiam o excedente no comércio de rua, como no caso de quitandeiras, vendedores de leite, legumes, lavadeiras, engomadeiras, mulheres que viviam do meretrício e larápios que sempre estavam à espreita de desavisados nos caminhos de Fortaleza para as serras próximas, áreas de refrigério, e para vilas do interior.

A Comissão de Socorros Públicos, que deveria gerir os recursos enviados por outras províncias ao Ceará visando a viabilizar certa assistência aos retirantes concentrados em abarracamentos relativamente distantes do núcleo urbano da capital, era composta por traficantes de escravos, como Joaquim da Gunha Freire e Luiz de Seixas Correia, respectivamente seu presidente e tesoureiro. A recomendação de liberais e de conservadores para essa comissão era a de que não gastasse o dinheiro à toa com os pobres deslocados do interior da província, mas que empregasse os recursos promovendo o trabalho dos mesmos em obras que dotassem o Ceará de infraestrutura. O jornal liberal $O$ Cearense, a esse propósito, recomendava que "trabalho e economia, eis os polos dentro dos quaes a presidencia [da província] tem de circunscrever sua acção benefica em favor das victimas da secca" ${ }^{\text {"2 }}$.

1 BOURDIEU, Pierre. O poder simbólico. 8. ed. Tradução Fernando Tomaz. Rio de Janeiro: Bertrand Brasil, 2005. p. 62.

2 Fundação Biblioteca Nacional (FBN) - Hemeroteca Digital do Brasil (HDB) - O Cearense, ano XXXI, n 36, Fortaleza, Quinta-feira, 26/04/1877, p. 01. Disponível em: <http://memoria. bn.br/pdf/709506/per709506_1877_00036.pdf>. Acesso em: 03 nov. 2014. 
O discurso valorizador do trabalho como vetor do progresso e da civilidade passou a ser recorrente nos anos que antecederam a abolição. Era o novo ethos do trabalho que orientava a relação das elites com os pobres, mediada pela polícia ${ }^{3}$. Pode-se caracterizar de elites os grupos de indivíduos comerciantes, no caso de Fortaleza, que se beneficiaram com a abertura da navegação por cabotagem com praças comerciais como Maranhão, Pernambuco e Rio de Janeiro; dentre estes, havia aqueles que fizeram fortuna com o tráfico interprovincial de escravos e com o aluguel de imóveis e de criados(as). O discurso que associava trabalho, disciplina e ordem informou a noção de que a questão social era assunto de polícia. Tal qual a polícia era acionada para capturar escravos fugidos, também passou a ser para reaver criado(a)s que empreendiam fuga do cativeiro doméstico de seus patrões e tutores, em caso de menores e ingênuos, categoria social criada pela Lei 2.040, de setembro de 1871. Isso se nota no anúncio intitulado "Um roubo", publicado n'O Cearense, em maio de 1881:

Pede-se a pessoa que tiver em sua casa a menor Maria Eduviges, tenha a bondade de a mandar trazer a casa n. 82 da rua do Senador Pompeu, donde evadiu-se na noite do dia 16 do corrente de 7 para 8 horas, levando um relógio, de ouro, e uma abotuadura de ouro.

Gratifica-se a pessoa que a trouxer ou der noticia e dita menor, e protesta o abaixo assignado haver ditos objectos da pessoa em cujo poder estiver dita menor. Fortaleza, 18 de Junho de 1881. Emiliano Correia Sedrim. ${ }^{4}$

Não há indicação de que a menor Maria Eduviges fosse ingênua, mas provavelmente era órfã tutelada por Emiliano Sedrim. Desde ten-

3 PESAVENTO, Sandra Jatahy. Trabalho livre e ordem burguesa: Rio Grande do Sul - 1870-1900. Revista de História, São Paulo, Universidade de São Paulo, n. 120, p. 135-151, 1989. p. 146

4 FBN - HDB - O Cearense, ano XXXV, n 93, Fortaleza, Quarta-feira, 04/05/1881, p. 02. Disponível em: <http://memoria.bn.br/pdf/709506/per709506_1881_00093.pdf>. Acesso em: 08 nov. 2014. 
ra idade, crianças pobres, principalmente órfãs, começavam a trabalhar, enquanto agregadas em casas de famílias. Ganhavam, em geral, apenas alimentação e a própria moradia, desde que reconhecessem seu lugar como "quase da família", agregadas, cativas pela condição mesma de servir aos donos da casa. Os patrões ou tutores, no caso das órfãs, tinham-lhes sob alguma tolerância, amiúde disfarçada de benemerência, até quando não rompessem certo acordo tácito de obediência e não esquecimento de seu "lugar" e "funções" na respectiva residência. Há registros de crianças trabalhando desde os cinco anos de idade, apesar de que somente aos sete a Igreja considerasse o indivíduo haver alcançado a idade da razão ${ }^{5}$. O arrolamento da população de Fortaleza de 1887 registrou casos assim, como o de José Bezerra, de cinco anos, que trabalhava na residência de Joaquim Guilherme d'Oliveira Castro, ou de Maria de Jesus, de três anos, que servia como agregada na casa de Maria do Rosário Brandão ${ }^{6}$.

Parece equívoco, ao preencher a documentação, de quem coletou e anotou as informações para composição do referido levantamento identificar no interior das casas crianças em idades tão tenras empregadas no "serviço doméstico". Todavia, José Roberto do Amaral Lapa referiu, para a realidade de Campinas, em São Paulo, a "precoce iniciação da criança escrava no trabalho, descendo até os 4 ou 5 anos, naturalmente para tarefas que exigissem pouca força e habilidade" ${ }^{\text {" }}$. O trabalho era estafante. $\mathrm{O}$ chefe interino de polícia Júlio de Vasconcelos, em 1881, registrou que "na capital, [se deu] a morte de uma infeliz menina de nome Maria, de 8 para 9 annos de idade, por servicias que lhe infligiram seu amo, Coriolano Fiusa Lima e a mulher deste" ". O fato repercutiu também nos jornais. O Cearense, em

5 MATTOSO, Kátia de Queirós. O filho da escrava (em torno da Lei do Ventre Livre). Revista Brasileira de História, São Paulo, v.8, nº 16, p. 37-55, 1. semestre 1988. p. 43.

6 Arquivo Público do Estado do Ceará (APEC) - Secretaria de Polícia - Arrolamento da População de Fortaleza, 1887, Livro 355.

7 LAPA, José do Amaral. Os excluídos: contribuição à história da pobreza no Brasil (1850-1930). Campinas, SP: Editora da UNICAMP, 2008. p. 185.

8 Center Reaserch Libraries - Relatórios de Presidentes de Província - Relatório do Chefe de Polícia Júlio Barbosa de Vasconcelos, de 1881, p. 15. Disponível em: < http://brazil.crl.edu/bsd/bsd/ 
10 de abril de 1881, informou que o senhor Coriolano Fiusa Lima e sua mulher "foram processados, sendo o primeiro julgado e absolvido pelo jury. $O$ Tribunal da Relação mandou submettel-o a novo julgamento"9.

Outra fuga de menor cativa no serviço doméstico foi divulgada em janeiro de 1884, ano oficial da abolição no Ceará. O Cearense trouxe o anúncio sob o título "Menina fugida", e no mesmo lia-se

Hontem desappareceo da casa do abaixo assignado uma menina de 12 para 13 annos de edade, côr parda, de nome Maria, natural da Amasonas. Suppôe-se ter sido seduzida por um preto para botar em outra casa de familia mediante alguma paga, pede portanto o mesmo abaixo assignado a pessoa a quem fór offerecida essa menina que lhe avise afim de cessar de si a responsabilidade para com alguem pela referida menina. Fortaleza, 19 de Janeiro de 1884. Vulpiano Cavalcante Araujo, Rua do Major Facundo n ${ }^{\circ} 6 .{ }^{10}$

Maria fizera o caminho inverso do que então realizavam trabalhadores emigrantes que buscavam ganhar a vida no norte do País. Era parda, descendente de negros, e estava em idade preferida por muitas famílias, entre 12 e 14 anos, a julgar pelos anúncios de aluguel de criados de servir. O que chama a atenção neste caso é a suposição de haver sido "seduzida por um preto" a fim de que fosse servir em outra residência. Essa hipótese acerca da fuga de Maria é seminal para pensar as relações de alocação de criados(as) e amas de leite em casas de família para realização de serviços domésticos ou outros serviços que viessem a lhes ser acrescentados na rotina de trabalho, na medida em que algumas casas eram ligadas a oficinas, lojas e escritórios, por exemplo.

u221/000016.html>. Acesso em: 26 jul. 12.

9 FBN - HDB - O Cearense, ano XXXV, n 77, Fortaleza, Domingo, 10/04/1881, p.01. Disponível em: <http://memoria.bn.br/pdf/709506/per709506_1881_00077.pdf>. Acesso em: 08 nov. 2014.

${ }^{10}$ FBN-HDB - O Cearense, ano XXXVIII, nº 16, Fortaleza, Domingo, 20/01/1884,p. 02. Disponível em: <http://memoria.bn.br/pdf/709506/per709506_1884_00016.pdf>. Acesso em: 13 nov. 2014. 
O aludido "preto", que seria o responsável pela fuga de Maria e por sua suposta escolha de trabalhar em outra casa, representaria uma prática que de algum modo deveria ser combatida e sanada através da regulamentação da alocação de criados de servir. Em 1887, estabeleceu-se que, quando se tratasse de menores de idade, o patrão ou patroa só poderia admitir o respectivo menor em qualquer função mediante a autorização de seus pais ou tutores. Isso foi também objeto do projeto de postura para o serviço doméstico de 1881. O que deveria ser limitada, na ótica das camadas dominantes, era a possibilidade de autonomia dos criado(a)s na escolha das casas em que trabalhariam. Ao se cogitar o fim da escravidão, não se admitiria a abolição da relação senhorial, tendo como epicentro de sua reprodução os espaços domésticos.

A premência da abolição do elemento servil levou as camadas dominantes a adotarem formas de permanência da escravidão, inclusive culturalmente, sobretudo no mundo do trabalho, que constitui locus privilegiado para a reprodução do habitus senhorial. Isto é, tratava-se de envidar dispositivos legais, a exemplo de códigos escritos, regulando o processo de contratação de trabalhadores. Além desses, haviam normas não escritas, mas igualmente eficazes na coerção e controle dos indivíduos "sujeitos" ao trabalho de servir. Tudo isso concorreu para tornar o ex-escravo e o pobre, nascido livre mas também compreendido na zona social onde a liberdade era estruturalmente precária ${ }^{11}$, em que se teciam experiências nas fronteiras entre escravidão e liberdade $^{12}$, um cativo no mundo do trabalho. A abolição da escravidão trouxe consigo a demanda do controle dessa liberdade conquistada. A condição civil e social seria matizada por vários fatores combinados, de ordem dinâmica, cotidiana e estrutural.

${ }^{11}$ CHALHOUB, Sidney. Precariedade estrutural: o problema da liberdade no Brasil escravista (século XIX). História Social, Campinas, SP, nº 19, p. 19-32, 2010. e LIMA, Henrique Espada. Sob o domínio da precariedade: escravidão e os significados da liberdade de trabalho no século XIX. Topoi, Rio de Janeiro, v. 6, nº 11, p. 289-326, 2. semestre 2005.

${ }^{12}$ Idem. A força da escravidão: ilegalidade e costume no Brasil oitocentista. São Paulo, Companhia das Letras, 2012. p. 254. 
Os mecanismos sociais de controle do trabalho dos pobres e do aproveitamento útil de sua liberdade povoaram os discursos públicos de abolicionistas e de traficantes de escravos. A ponto, inclusive, de se ver, no início dos anos 1880, traficantes de escravos anunciando criado(a)s e amas de leite para aluguel. Havia indivíduos que concorriam, no circuito de negócios da cidade, como agentes da contratação de criados(as) de servir. Um certo senhor Motta fez saber que: "CREADA. Precisa-se de uma, a tratar com o agente Motta, á praça do Ferreira n. 2"13. Tanto comerciantes de escravos, como abolicionistas apareciam nos jornais de então enquanto agentes no mercado de alocação de criado(a)s, fossem livres ou escravos. Isaac Amaral, abolicionista, assinou, em julho de 1890, anúncio em que se lia: "Creada. Preciza-se de uma para lidar com creanças e arranjos de uma casa" ${ }^{14}$. N'O Cearense, de outubro de 1881, encontrava-se: "Criada. Precisa-se de uma em casa de: João Cordeiro"15, que também era um destacado abolicionista. Os irmãos Albano, políticos e filantropos cearenses favoráveis a libertação dos escravos, vieram a público, através d'O Cearense, informar que pretendiam alugar uma: "COSINHEIRA. Aluga-se e paga-se bem uma boa. Albano E Irmão"16.

Destaca-se desse anúncio, dos irmãos Albano, o termo alugar, que tinha o sentido de contratar por período determinado ou indeterminado, a depender, entre outros motivos, do comportamento do(a) criado(a). Mas nem sempre o contrato era efetivado; sobretudo, quando a relação não se dava entre senhores. Era bastante comum chefes de família responsabilizarem-se pela criação de meninos e meninas, podendo, em troca, empregá-los nos serviços domésticos. Crianças órfãs, abandonadas e/ou ingênuos eram criados para servir como servos,

${ }^{13}$ FBN - HDB - O Cearense, ano XLIV, no 103, Fortaleza, Domingo, 11/05/1890, p. 03. Disponível em: <http://memoria.bn.br/pdf/709506/per709506_1890_00103.pdf>. Acesso em: 19 jan. 2017.

${ }^{14}$ FBN - HDB - Libertador, ano X, no 156, Fortaleza, Quarta-feira, 09/07/1890, p. 04. Disponível em: <http://memoria.bn.br/pdf/229865/per229865_1890_00156.pdf>. Acesso em: 18 jan. 2017.

${ }^{15}$ FBN - HDB - O Cearense, ano XXXVI, nº 233, Fortaleza, 29/10/1881, p. 04. Disponível em: <http://memoria.bn.br/pdf/709506/per709506_1881_00233.pdf>. Acesso em: 21 jan. 2017.

${ }^{16}$ FBN - HDB - O Cearense, ano XLIV, n ${ }^{\circ} 114$, Fortaleza, Domingo, 25/05/1890, p. 03. Disponível em: <http://memoria.bn.br/pdf/709506/per709506_1890_00114.pdf>. Acesso em: 19 jan. 2017. 
como criado(a)s de servir. Nesses casos, os tutores, em geral, não lhes pagavam salário algum. Tendia-se a enxergar nessa entrega dos filhos para o trabalho doméstico um ato benemérito para com os pais pobres.

N'O Cearense, de 4 de dezembro de 1881, encontra-se um informe que denota o objetivo de receber em casa, especificamente, uma criança do sexo feminino: "acceita-se para casa d'uma familia, uma menina de 10 a 12 annos, a quem se dará de comer e vestir e se ensinará todo o serviço domestico de uma casa, como: seja coser, engommar, etc. A quem convier dirija-se a rua da BôaVista $n^{0} 112^{\prime \prime}$. A proposta consistia na educação da criança conforme a sua destinação social. Pobres nascidos para servir deveriam receber instrução para tal. Desse modo, seriam preparados para tornarem-se cidadãos. Até ingênuos deveriam ser afastados das mães escravas a fim de que não crescessem com algum vício moral do cativeiro. A instrução para a cidadania dessas pessoas passaria, nessa perspectiva, pelos afazeres domésticos, domesticando-se através do trabalho no seio da reprodução do habitus senhorial - a moradia burguesa.

Alugar, todavia, referia-se também à possibilidade de tomar um escravo pertencente a outrem para trabalho. Um grande comerciante de Fortaleza avisou, aos que procuravam escravos, que vendia ou alugava "cinco escravas moças e prendadas, um moleque, dois negros de 40 annos e um negro bom cosinheiro: quem os pretender, dirija-se ao escriptorio de Luiz R. da Cunha E̊ Sobrinhos" ${ }^{\prime 18}$. No sentido estrito, só se aluga aquilo ou aquele(a) sobre o qual se tem direito de propriedade. Portanto, era uma prática corriqueira oferecer escravos ao aluguel de terceiros. No tocante a pessoas livres dadas ao aluguel por um patrão ou tutor, configurava-se aí uma redução de indivíduos livres à condição servil, crime previsto no Art. ${ }^{\circ} 179$ do Código Criminal do Império ${ }^{19}$. O termo alugar con-

${ }^{17}$ FBN-HDB - O Cearense, ano XXXVI, no 263, Fortaleza, Domingo, 04/12/1881, p. 03. Disponível em: <http://memoria.bn.br/pdf/709506/per709506_1881_00263.pdf>. Acesso em: 21 jan. 2017.

${ }^{18}$ FBN - HDB - O Cearense, ano XXV, nº 117, Quarta-feira, 11/10/1871, p. 03. Disponível em: <http://memoria.bn.br/pdf/709506/per709506_1871_00117.pdf>. Acesso em: 18 jan. 2017.

${ }^{19}$ Senado Federal - Biblioteca do Senado Federal - Obras Raras - Código Criminal do Imperio do Brasil. Recife: Typographia Universal, 1858. p. 74. Disponível em: <http://www2.senado.leg.br/ bds/handle/id/221763>. Acesso em: 28 fev. 2017. 
tinuou sendo usado depois de declarada a abolição do trabalho servil, no Ceará; do que se depreende que certas relações sociais e de trabalho conservaram características objetivas e simbólicas da escravidão, mantendo vivo um habitus senhorial na cultura e no âmbito das interações entre indivíduos socialmente desiguais.

Luiz Ribeiro da Cunha, que ofereceu escravos para aluguel ou compra no anúncio citado, era um comerciante português que fez fortuna na praça comercial do Ceará. Era representante, ali, de companhias de navegação por cabotagem, vendia e alugava imóveis em Fortaleza e no seu entorno e traficava escravos. No começo de 1880, doou o vasto terreno da Canafistula ao governo da província. Tratava-se de uma área próxima à Estrada de Ferro de Baturité, construída pela mão de obra de retirantes, que deixaram inúmeras crianças órfãs nos abarracamentos nos quais eram confinados. A Colônia Christina era uma entidade de caráter agrícola e orfanológico, criada para acolher os desvalidos que fugiam da seca de 1877-79, crianças abandonadas e sem pais.

Para se manterem, as crianças internas naquela colônia arrancavam troncos de árvores que eram vendidas para a Companhia da Estrada de Ferro de Baturité - que tinha Joaquim da Cunha Freire como um dos principais acionistas. No artigo $11^{\circ}$ do regulamento da Colônia Christina estava previsto que se "providenciará sobre a collocação e emprego dos orphãos, concluida a sua educação" ${ }^{20}$. Os internos eram "na maxima parte filhos do campo, [e cuidava-se para que] recebessem educação apropriada a seu destino social". Tratava-se, conforme seu regulamento de 1884, de "habilital-os a serem cidadãos uteis á patria e á familia"21. Instrução, destino social e úteis são topônimos que atestam o sentido daquela colônia: uma fábrica de indivíduos utilizáveis ${ }^{22}$. Concebida para

${ }^{20}$ FBN - HDB - O Cearense, ano XXXVI, no 215, Fortaleza, Sábado, 08/10/1881, p. 01. Disponível em: <http://memoria.bn.br/pdf/709506/per709506_1881_00215.pdf>. Acesso em: 05 out. 2016.

${ }^{21}$ FBN-HDB-O Cearense, ano XXXVIII, nº 87, Fortaleza, Sexta-feira, 25/04/1884, p. 01. Disponível em: <http://memoria.bn.br/pdf/709506/per709506_1884_00087.pdf>. Acesso em: 07 out. 2016.

${ }^{22}$ GONÇALVES, Adelaide. "Uma fábrica de homens utilizáveis: sobre escola e instrução pública para os pobres no Ceará". In: RIOS, Kênia Sousa; FURTADO FILHO, João Ernani. Em tempo: História, memória, Educação. Fortaleza: Imprensa Universitária, 2008. p. 81-110. 
instruir os internos ao trabalho agrícola, terminou por se tornar um centro de treinamento de meninos e meninas para atender a demanda por criado(a)s, na medida em que recebia petições requerendo "orphans á tutela para serviço domestico" "23. Quem assinava a concessão de rapazes e moças para serem tutelados era o presidente da mesa diretora da Colônia Christina, isto é, Luiz Ribeiro da Cunha - que, nesse contexto, praticava o tráfico de escravos.

Lorena Teles adverte que "as raízes históricas do trabalho doméstico estão na escravidão" 24 , conquanto por bom tempo a história social do trabalho não tenha admitido os escravos como sujeitos do seu escopo historiográfico ${ }^{25}$, assim como pairou certa compreensão, até os dias mais recentes, de que os serviços domésticos distinguir-se-iam da ideia de trabalho, na medida em que quem os pratica não assumiria posição na produção e circulação de bens na sociedade. ${ }^{26}$ Sobretudo no Ceará, onde prevalecia uma escravidão de pequenos proprietários no campo e nas cidades, em que se "precisava de escravos mais para o trabalho doméstico"27.

Aliás, os anúncios de aluguel de criados de servir disputavam espaço nos jornais com os de venda de escravos, e na medida em que os anúncios de venda de cativos foram escasseando, na proporção da saída de escravos pelo tráfico interprovincial e aumento das libertações, os avisos de aluguel de trabalhadores em serviços domésticos tornaram-se mais comuns nos periódicos. Não era raro ler a respeito de fuga de criados forros ou livres das residências em que serviam, pois ali se

${ }^{23}$ FBN - HDB - Gazeta do Norte, ano II, no 23, Sábado, 28/01 / 1882, p. 03. Disponível em: < http:// memoria.bn.br/pdf/103950/per103950_1882_00023.pdf>. Acesso em: 18 jan. 2017.

${ }^{24}$ TELES, Lorena Feres da Silva. Libertas entre sobrados: mulheres negras e trabalho doméstico em São Paulo (1880-1920). São Paulo: Alameda, 2014. p. 23.

${ }^{25}$ Há vasta discussão sobre esse tema, dentre outros, ver: CHALHOUB, Sidney; SILVA, Fernando Teixeira da. Sujeitos no imaginário acadêmico: escravos e trabalhadores na historiografia brasileira desde os anos 1980. Cadernos AEL, Campinas, SP, v. 14, n.26, p. 13-45, 2009.

${ }^{26}$ SAFFIOTI, Heleieth Iara Bongiovanni. Emprego doméstico e capitalismo. Petrópolis: Vozes, 1978. passim. e TELES, Lorena Feres da Silva. Op. Cit. passim.

${ }^{27}$ SCHIMMELPFENG, Gisela Paschen. A mulher e a abolição. Fortaleza: Secretaria de Cultura e Desporto, 1984. p. 24. 
deparavam muitas vezes com "uma espécie de escravidão disfarçada, a serviço de uma família que lhes desse abrigo" 28 . No caso das mulheres, além de abrigo, procurava-se proteção - muito embora conjugada com poder num espaço de coabitação entre patrão e criada.

De acordo com Olívia Maria Gomes da Cunha, ambiente doméstico constitui um domínio avesso às leis positivas estabelecidas pelo Estado. Ali, onde em geral prevaleciam a vontade e desejo privados dos chefes de domicílio e dos cabeças de família, constituir-se-ia o território da reprodução social ${ }^{29}$. Esse era o caminho esboçado para os pobres, sobretudo para os que ainda não haviam alcançado a maioridade, como observa Amaral Lapa, em Campinas, a respeito de órfãs que tinham no Asilo "a condição de 'escola' de empregadas domésticas" 30 .

Seria um erro apresentar como contradição o fato de negreiros que animavam o tráfico interprovincial tomarem parte no processo de libertação de escravos no Ceará. Quando se tornou empreendimento reprovável, boa parte assumiu publicamente o discurso favorável à abolição e à regulação do trabalho dito livre. O jornal $A$ Constituição, do próprio barão de Ibiapaba, tratou assim da questão:

nunca declaramos que o Sr. Joaquim da Cunha Freire \& Irmão não mantinham commercio de escravos, e nem podíamos fazel-o, desde que é notoriamente sabido que Ss. Ss. tem algumas vezes negociado com esse gênero de commercio, que, embora muito triste e afflictivo, não deixa comtudo de ser muito legal e licito, do qual fazem uso em grande escala negociantes muito honrados desta praça, como sejam, por exemplo, os Srs. Luiz Ribeiro da Cunha \& Sobrinhos, Viuva Salgado \& Comp., Francisco Rocha, Cunhada \& Sobrinhos e Francisco Coelho da Fonseca \& Filho, etc. ${ }^{31}$

${ }^{28}$ LAPA, José Roberto do Amaral. A cidade: os cantos e os antros: Campinas 1850-1900. São Paulo, SP: Editora da USP; Campinas, SP: Editora da UNICAMP, 2008. p. 227.

${ }^{29}$ CUNHA, Olívia Maria Gomes da. Criadas para servir: domesticidade, intimidade e retribuição. In: ___ GOMES, Flávio dos Santos (Orgs.). Quase-cidadão: histórias e antropologias da pós-emancipação no Brasil. Rio de Janeiro: Editora FGV, 2007. p. 376-417.

${ }^{30}$ LAPA, José Roberto do Amaral. A cidade. Cit. p. 227.

${ }^{31}$ FBN - HDB - A Constituição, ano XII, no 136, Fortaleza, Domingo, 18/10/1874, p. 03. Disponível em: <http://memoria.bn.br/pdf/235334/per235334_1874_00136.pdf>. Acesso em: 12 jun. 2015. 
Luiz de Seixas Correia e Luiz Ribeiro da Cunha se fizeram presentes, como diretores, no ato de fundação do Centro Abolicionista 25 de Dezembro, que teve lugar no Reform Club a 19 de dezembro de 1882. Virgínia Salgado, dona da firma Viúva Salgado \& Comp., que também negociava escravos e ofertava para aluguel criados de servir, integrou sociedade abolicionista "das distintas filhas do Ceará, das dignas irmãs de Iracema" " ${ }^{2}$. Na reunião de fundação da sociedade, em que se sagrou uma das diretoras, em 18 de dezembro de 1882, numa chácara no Benfica pertencente ao também abolicionista José do Amaral, teriam sido expedidas cartas de alforria a seis escravos ${ }^{33}$. A historiografia tradicional da abolição tratou-a como "abolicionista de primeira linha, [que] lutou sempre com entusiasmo pela causa da libertação dos escravos"34.

Joaquim da Cunha Freire, por sua vez, figura na relação de escravos matriculados na Alfândega do Ceará até 11 de janeiro de 1881 como possuidor de 13 cativos, sendo 4 do sexo feminino e 8 do masculino. Mas um deles estava em nome da firma Joaquim da Cunha Freire \& Irmão. ${ }^{35}$ Alguns deles receberam cartas de alforria naquele mesmo ano. Foi o caso de Antonio, casado e matriculado na Alfândega ${ }^{36}$. Antonio era preto, tinha 32 anos e pertencia a Francisco Roza Nunes de Mello. Certamente, o barão de Ibiapaba adquiriu-o para fazer honras à Sociedade Cearense Libertadora, libertando-o em seguida, juntamente com Claudina, mulher do dito escravo, matriculada sob o $\mathrm{n}^{\circ} 1393$.

Frequentando eventos em salões no teatro da abolição onde se organizaram associações libertadoras, no começo da década de 1880, Joaquim da Cunha Freire concedeu alforria a oito escravos ${ }^{37}$. Certamen-

\footnotetext{
${ }^{32}$ GIRÃO, Raimundo.AAboliçãono Ceará.3.ed.Fortaleza:SecretariadeCultura e Desporto, 1984.p. 153.

${ }^{33}$ SCHIMMELPFENG, Gisela Paschen. Op. Cit., p. 26.

${ }^{34}$ Ibidem., p. 56-57.

${ }^{35}$ APEC - Juntas Classificadoras de Escravos - Relação de escravos matriculados na Alfândega do Ceará - 11 de janeiro de 1881 .

${ }^{36}$ Matrícula n ${ }^{\circ}$ 536. Biblioteca Pública Governador Menezes Pimentel - Setor de Microfilmes Libertador, ano I, nº 19, Fortaleza, 28/09/1881. p. 07.

${ }^{37}$ GIRÃO, Raimundo. Op. Cit. p. 156.
} 
te, esses libertados estavam entre os inscritos na Alfândega. O Censo de Fortaleza de 1887 informa que o barão de Ibiapaba, morador em sobrado de $\mathrm{n}^{\circ}$ 46, na Rua do Major Facundo, vizinho da redação do órgão abolicionista Libertador, sustentado pela Sociedade Cearense Libertadora, mantinha em sua casa o criado José, um africano de 70 anos que era cozinheiro ${ }^{38}$. Este era mantido sob condição cativa. O fato de haver um africano trabalhando como cozinheiro para um dos principais traficantes de escravos do Império testemunha a favor da hipótese de que o serviço doméstico concorreu, na passagem do século XIX para o XX, como espaço privilegiado para a manutenção de laços senhoriais na sociedade e que estavam ainda em bastante evidência no imediato pós abolição no Ceará.

O bacharel em direito e escritor Yaco Fernandes, em glosa transcrita no capítulo "A farsa dos libertadores", que compõe o livro póstumo "Notícia do povo cearense", registrou versos que captam bem o olhar senhorial com o qual os negros pobres em geral eram fitados: "Negro, encurta essa lingua,/Vai conhecer teu lugar;/Olha que eu sou homem branco,/ Nascido para mandar;/ Eu não sou da tua igualha,/Muleque pé de sambar"39. Os versos aludidos por Yaco Fernandes conformariam com outras partes um desafio entre um caboclo e um negro, no qual o primeiro evoca a metáfora de Caim como figura da ancestralidade amaldiçoada do afrodescendente. Nota-se que o caboclo se diz branco e por isso arroga para si o direito natural de mandar, de ser senhor. De modo que o habitus senhorial perpassava diferentes camadas sociais, ao ponto de se ter indivíduos bastante próximos do ponto de vista da hierarquia social se arvorando autoridade sob o outro de cor de pele escura. A abolição não rompeu esse habitus senhorial, que se perpetuou na sociedade e estava presente, particularmente, nos espaços domésticos e nas relações de poder a estes correlatos. A abolição, conquanto tenha tido um sentido de

\footnotetext{
${ }^{38}$ APEC - Governo do Estado - Secretaria de Polícia - Arrolamento da População de Fortaleza, 1887. ${ }^{39}$ FERNANDES, Yaco. Notícia do povo cearense. 2. ed. Fortaleza: CASA DEJOSÉ DE ALENGAR/ UFC, 1998. p. 176.
} 
conquista política para os escravos, como defendeu Sidney Chalhoub ${ }^{40}$, tratou-se também de uma reposição de hierarquias ${ }^{41}$. Como sintetizou Wlamyra de Albuquerque, a abolição nem se tratou da conquista plena da liberdade, nem de uma fraude absoluta, mas de ocasião de disputa em torno dos sentidos da liberdade de uma população de cor $^{42}$.

Nesse contexto de tensões e disputas acerca dos sentidos da liberdade civil dos negros escravizados, mas também de regulamentação do trabalho dito livre, comerciantes negreiros, parte desses tornados abolicionistas, fizeram-se mais presentes através de discursos na imprensa. A comissão organizada para dar cabo à libertação dos últimos cativos no Ceará era quase toda composta por reconhecidos senhores e traficantes de escravos. Entre os quais, pelo que se sabe, barão de Ibiapaba, barão de Aquiraz, Luiz Ribeiro da Cunha e Luiz de Seixas Correia. João Cordeiro, presidente daquela sociedade abolicionista, havia sido sócio do barão de Ibiapaba numa firma aberta em Mossoró, cidade do Rio Grande do Norte ${ }^{43}$. Não é de se estranhar que houvesse abolicionistas comprometidos com a propriedade escravista; trata-se, antes, de perscrutar as relações de comerciantes enriquecidos com o tráfico de homens e mulheres escravizados, com a concepção da libertação do elemento servil no Ceará, bem como com medidas de regulação do trabalho dito livre, em particular dos serviços domésticos, que passam por processo de valorização na década de 1880, em várias províncias e, inclusive, na Corte enquanto modo de disciplinar os pobres $^{44}$ e embutir-lhes a moral do trabalho.

${ }^{40}$ Cf. CHALHOUB, Sidney. Visões da liberdade: uma história das últimas décadas da escravidão na corte. São Paulo: Companhia das Letras, 1990.

${ }^{41}$ SCHWARCZ, Lilia Moritz. Dos males da dádiva: sobre as ambigüidades no processo de Abolição brasileira. In: CUNHA, Olívia Maria Gomes da; GOMES, Flávio dos Santos (Orgs.). Op. Cit. p. 26-27.

42 ALBUQUERQUE, Wlamyra R. de. O jogo da dissimulação: abolição e cidadania negra no Brasil. São Paulo: Companhia das Letras, 2009. p. 97.

43 Conquanto tenha sido considerado por Clóvis Moura "o maior abolicionista do Cearáa". MOURA, Clóvis. Dicionário da escravidão negra no Brasil. São Paulo: Editora da Universidade de São Paulo, 2004. p. 116.

${ }^{44}$ CUNHA, Olívia Maria Gomes da. Criadas para servir: domesticidade, intimidade e retribuição. In: ; GOMES, Flávio dos Santos (Orgs.). Op. Cit. p. 382. 
Luiz Ribeiro da Cunha também ganhou espaço entre os abolicionistas da Sociedade Cearense Libertadora e publicou no seu jornal, Libertador, carta em que louvava a campanha abolicionista e o sagrado direito de liberdade dos escravizados. Nesta carta, dizia que "a abolição da escravatura no Brasil não póde mais considerar-se um problema de difficil solução; e assim é, porque o santo amôr pela liberdade brota hoje espontaneo de todo o coração brasileiro: o espirito publico se revoluciona contra a escravidão." ${ }^{45}$. E completava: "na minha obscuridade, não posso deixar de associar-me de coração aos valorosos" ideais da abolição.

Alguns meses antes disso, veiculou-se anúncio sobre a pretensão de Luiz Ribeiro da Cunha de arrendar sítio na Jacarecanga. Lugar de morada e veraneio de ricos comerciantes de Fortaleza. O anúncio referido mencionava que se tratava do sítio São Luiz "com grande casa de vivenda, preparada e aceiada de novo, com mobilia, muitos coqueiros botadores, cajueiros e outras fructeiras, grande baixa com capim plantado de novo, muita macaxeira e mandioca, agua corrente e abundante, e grande poço de agua potavel"46. E mais: "tem calçamento até ao terraco da casa. Contrata-se por nunca menos de trez annos e alluga-se tambem alguns escravos para o serviço. Quem pretender queira entender-se com o proprietario Luiz Ribeiro da Cunha". Os interessados no aluguel desse sítio saberiam, ao ler o anúncio, que contariam com escravos para o trabalho de manutenção e para a lida na cozinha. $\mathrm{O}$ serviço doméstico era realizado quer por escravos ou forros, quer por pobres ditos livres que igualmente disputavam sua sobrevivência ocupando-se em "casa de família" e realizando funções dentro e fora das residências, expandindo o sentido estrito de serviço doméstico.

Anúncios de contratação de amas de leite e criados de servir dividiam espaço nas seções de anúncios dos periódicos com avisos de fuga ou venda de escravos. Luiz Ribeiro da Cunha publicou no fornal da Fortaleza, em 1879: "vende-se um cazal de escravos pretos ainda moços e de bons costumes por preço rasoavel a quem convier, entenda-se com Luiz R. da Cunha

${ }^{45}$ BPGMP - Setor de microfilmes - Libertador, ano 1, $\mathrm{n}^{\circ}$ 19, 28/09/1881, p. 03.

${ }^{46}$ FBN - HDB - Pedro II, ano 41, no 49, Fortaleza, Quinta-feira, 23/06/1881, p. 04. Disponível em: <http://memoria.bn.br/pdf/216828/per216828_1881_00049.pdf>. Acesso em: 04 set. 2014. 
Sobrinhos ${ }^{\prime 4}$. Em abril de 1884, pouco depois de considerada livre oficialmente de escravos a província cearense, Luiz Ribeiro da Cunha declarou no Libertador que precisava de cozinheira ${ }^{48}$. O que não deixa evidente é se era para trabalhar em sua própria residência ou em outra propriedade sua que estivesse arrendada. Nem especificou preferência por livre ou escrava, o que era comum nos anúncios das décadas de 1860 e 1870. Importantes comerciantes de escravos investiam seu lucro em imóveis para serem alugados, em alguns casos oferecendo escravos ou pobres livres para os serviços de criadagem.

O que estava em jogo, nos últimos anos da escravidão no Ceará era a questão do trabalho, nomeadamente do controle dos trabalhadores e, em geral, dos pobres, tanto através de posturas municipais como de regulamentação das relações de trabalho, com ênfase no serviço doméstico. Não foi à toa que em 1881, a Câmara de Fortaleza, presidida por Joaquim da Gunha Freire, tentou regular as relações de contratação de criados de servir. $\mathrm{O}$ anteprojeto que fora apreciado naquela casa previa penas de pagamento de multa para ambas as partes, porém as hipóteses de cumprimento de prisão na Cadeia Pública só diziam respeito aos criados que infringissem às normas estabelecidas pela municipalidade e observadas pela polícia.

Isto já bastaria para pensar a respeito da seguinte questão: qual o interesse no controle dos pobres nos últimos anos de vigência oficial da escravidão?

Numa carta aberta ao chefe de polícia de então, Christiano Benedicto Ottoni considerou que "um dos vicios que prepondera nas classes inferiores da provincia é a vagabundagem, vivendo muitos individuos sem occupação honesta e util de que possam subsistir" ${ }^{\prime 9}$. E segue, citando teorias crimino-

${ }^{47}$ FBN - HDB - Jornal da Fortaleza, ano II, no 218, Fortaleza, Sexta-feira, 01/03/1879, p. 04. Disponível em: <http://memoria.bn.br/pdf/per721247_1879_00218.pdf>. Acesso em: 09 abr. 2015.

${ }^{48}$ FBN - HDB - Libertador, ano IV, n ${ }^{\circ}$ 65, Fortaleza, Quarta-feira, 02/04/1884, p. 03. Disponível em: <http://memoria.bn.br/pdf/229865/per229865_1884_00065.pdf>. Acesso em: 19 abr. 2014. 49 APEC - Governo da Província - Chefatura de Polícia - Ofícios. Carta de Christiano Benedicto Ottoni, 1884. 
logistas de Arnould Bonneville de Marsangy (1802-1894), então em voga: "a lei pune os vagabundos, por que o individuo que não tem fogo, morada, nem meios de subsistencia, e não exerce habitualmente nenhuma profissão, é por isso mesmo forçosamente predisposto ao crime". Ottoni arrematou seu argumento afirmando que "n'esta capital especialmente é grande a classe a que me referi, e em falta de outra lei de trabalho, a execução recommendada augmentará o numero dos criados de servir em condicções de satisfazerem os reclamos da população". $\mathrm{Na}$ visão de Ottoni, caberia ao chefe de polícia empregar meios "efficazes para a cessação do crime e para a realização do trabalho".

Esse discurso era coevo com o imaginário social hegemônico acerca dos pobres e constituía óbice à possibilidade de conquista da cidadania por parte dos negros escravizados e mesmo de pobres ditos livres. Havia o argumento de que os negros escravizados, acostumados com o cativeiro, não saberiam lidar com o direito civil de liberdade. $\mathrm{O}$ positivismo jurídico e o utilitarismo econômico - ambos, grosso modo, irmanados desde Jeremy Bentham e John Stuart Mill ${ }^{50}$ - informou certa visão da lida do governo com os pobres, sobretudo urbanos. Estes destoavam, nessa ótica, de reformas urbanas acompanhadas por Código de Posturas definidos pela municipalidade. De modo que se fazia necessário enquadrar condutas tidas como inadequadas e imorais em tipos criminais cada vez mais bem definidos, o que demandará uma Justiça e Polícia estruturadas e atuantes no sentido de ordenar as condutas de trabalhadores na esfera pública.

Justiça e polícia irmanaram-se para dar base à construção da ordem burguesa no país. As instituições de controle ou coerção social fazem a política dos grupos dirigentes. Thomas Holloway, analisando a constituição de forças armadas do Estado ao longo do século XIX, traçou uma relação entre política e polícia, destacando as semelhanças entre as funções políticas e sociais desta, que atesta tal perspectiva ${ }^{51}$.

\footnotetext{
${ }^{50}$ BOBBIO, Norberto. Liberalismo e democracia. 6. ed. Tradução Marco Aurélio Nogueira. São Paulo: Brasiliense, 2000. p. 64.

${ }^{51}$ HOLLOWAY, Thomas H. Polícia no Rio de Janeiro: repressão e resistência numa cidade do século XIX. Tradução de Francisco de Castro Azevedo. Rio de Janeiro: Editora Fundação Getúlio
} 
Para Gizlene Neder, a polícia assumiu um papel importante como instrumento técnico na ordenação da vida social, combatendo a criminalidade"52. Passou a produzir uma sorte variada de conhecimentos técnicos sobre a produção e o seu governo na cidade e nos arredores desta, mediadores que eram entre o modo de vida citadino e a produção rural. Coube à polícia organizar mapas estatísticos, regulamentar relações de trabalho, zelar pela higiene da cidade e garantir a ordem pública em função da propriedade privada.

A tentativa de hegemonia burguesa na ordem social, na estruturação de instituições e nos valores culturais exigiu a eficácia e sofisticação das instituições de coerção social, como a polícia e a Justiça. O que estava em jogo era a viabilização de uma articulação sob novas bases da relação Estado e sociedade, que não passaria mais por relações escravistas, mas por relações pretensamente liberais utilitárias e positivas, porque embasadas em preceitos legais redigidos, que constituiriam códigos penal e civil. Paula Ramos Junior, como outros juristas, advertiu: "vivemos felizmente sob o regimen de leis penaes escriptas" 53 , seriam elas "as forças moraes que dirigem as nações, o bello social que civilisa os costumes, e faz o bem estar dos povos". Aqui, cabe frisar, trata-se da ideia do direito positivo, do qual o Estado seria a única fonte produtora, como vetor e paradigma de uma sociedade civilizada, capaz de polir os costumes dos indivíduos. Polir, polido, estão semanticamente ligados a policiado ou civilizado ${ }^{54}$. Essa aparente liberalidade não passava de discurso público, pois mascarava a manutenção do paternalismo, do habitus senhorial, inclusive de relações escravistas.

Vargas, 1997. p. 152-153.

${ }^{52}$ NEDER, Gizlene. Discurso jurídico e ordem burguesa no Brasil. Porto Alegre: Sergio Antonio Fabris Editor, 1995. p. 21.

${ }^{53}$ JUNIOR, A. de Paula Ramos. Comentário ao código criminal brasileiro. Rio de Janeiro: Carioca, 1875. p. 13.

${ }^{54}$ STAROBINSKI, Jean. As máscaras da civilização: ensaios. Tradução de Maria Lúcia Machado. São Paulo: Companhia das Letras, 2001. p. 25. Ver também: DARNTON, Robert. Os dentes falsos de George Washington: um guia não convencional para o século XVIII. Tradução José Geraldo Couto. São Paulo: Companhia das Letras, 2005. p. 111. 
Gizlene Neder deu a ver, em "Discurso jurídico e ordem burguesa...", a relação entre o processo de criminalização e o de constituição do mercado de trabalho durante a vigência da escravidão e no pós abolição. Ganharam força nos anos iniciais da década de 1880 discursos apologéticos do trabalho e da disciplina. Há uma complementaridade promíscua entre ambos os conceitos. Trabalho para haver mais disciplina social, porque assim haveria mão de obra disponível. Para tanto, a repressão na cidade, obstaculizando o direito a esta, e o constrangimento dos pobres ao trabalho constituíram estratégias de comerciantes e dirigentes para manter subordinados aqueles que tinham no horizonte a liberdade, mesmo sob outra relação de poder e trabalho. " $A$ disciplina é, então, concebida como atrelada ao trabalho" 55 , sintetiza Neder, "ressaltamos que os dois movimentos caminham juntos: de um lado, a colocação do discurso que despreza a 'vagabundagem'. De outro, as práticas de controle e de 'correção' fundadas numa disciplina organizada para o trabalho".

\section{A polícia e a regularização do trabalho em Fortaleza}

Os pobres estavam na mira da polícia nas últimas décadas do Oitocentos. Jornais coevos dão conta da perseguição e repressão aos anônimos, ébrios e ociosos que vagavam nas ruas da cidade. A polícia buscou, sobretudo a partir da década de 1880, não apenas sofisticar seu poder repressivo, como dotar-se de saberes técnicos a respeito da população, distinguindo os ativos, úteis daqueles inúteis para a produção de bens materiais. A estatística concorre, então, como uma ciência que pode dar a conhecer os objetos e conteúdos necessários à administração de um Estado. A estatística deveria compor o organismo administrativo do Governo e ser decisiva na gestão dos problemas sociais enfrentados pelo poder público. Coerente com tal perspectiva, a província cearense cuidou logo em preparar o arrolamento da população de sua capital, demanda a cargo da qual ficou a Secretaria de Polícia. De

${ }^{55}$ NEDER, Gizlene. Op. Cit., p. 96. 
acordo com tal atribuição, o arrolamento da população de Fortaleza, em 1887, foi realizado sob os auspícios de Olímpio Manoel dos Santos Vital, o mesmo que apresentou, também em 1887, o Código de Posturas para o serviço doméstico na capital cearense - em muitos aspectos reeditando o projeto de lei de 1881 que se tentou aprovar na Câmara.

A polícia, como instituição estratégica para o governo dos pobres e para manutenção do habitus senhorial uma vez abolida a escravidão, realizava a política da ascendente burguesia senhorial, distinguida socialmente pela atividade comercial em Fortaleza, na segunda metade do século XIX. Antes da libertação dos cativos, caçava escravos fugidos e ingênuos que trabalhavam em casas de tutores, ou mesmo alugados a terceiros. No pós abolição, policiava as relações de trabalho, particularmente referentes ao serviço doméstico, observando o cumprimento do que previa o regulamento dessa atividade redigido em 1887. Quando foram positivados em forma de código escrito, os privilégios e obrigações de patrões, criado(a)s e amas de leite, em boa medida, já vigiam como costumes no âmbito do paternalismo.

Desde há muito se sabe, a polícia "só chega a ter assomos de energia com esses infelises que nada são e que nada podem" "56. A Cadeia Pública, instrumento de poder e correção punitiva do Estado, bem como a sua representação simbólica junto à sociedade, concorreu para a "consolidação da nova ordem social, fundamentada no cerceamento das redes de sociabilidade e na domesticação de trabalhadores" ${ }^{57}$. O discurso do trabalho corretor de condutas das ditas "classes inferiores" direcionava-se para desde os presos encarcerados naquela instituição disciplinar, passando pelos escravos e forros, até os pobres havidos por livres.

As atribuições da Casa de Correção, como era tida a Cadeia Pública, passavam pelo lugar de confinamento dos socialmente inadequados, infratores, vadios - recinto onde senhores guardavam escravos que

\footnotetext{
${ }^{56}$ FBN - HDB - Libertador, ano III, no 159, Fortaleza, Quarta-feira, 25/07/1883, p. 02. Disponível em: <http://memoria.bn.br/pdf/229865/per229865_1883_00159.pdf>. Acesso em: 17 mai. 2014.

${ }^{57}$ MARIZ, Silviana Fernandes. Oficina de Satanás: a Cadeia Pública de Fortaleza (1850-1889). 2004. 386f. Dissertação (Mestrado). Universidade Federal do Ceará, Fortaleza, 2004. p. 98.
} 
queriam pôr à venda e não tinham como mantê-los na própria casa e, ainda, servia para "ensinar oficios aos escravos domésticos ou mesmo puni-los"

Portanto, a Justiça e a Polícia constituíram forças legais que se articularam para tornar precária a liberdade dos que conquistavam a alforria ou empreendiam fuga durante a vigência oficial da escravidão no Brasil, e, em particular, no Ceará; bem como para impedir o acesso à cidadania quando da abolição. Não é por acaso que nesse poder e nessa instituição o habitus senhorial é facilmente percebido. Atestam isso denúncias de abuso de poder e desvio de atribuições do cargo sobre magistrados e chefes de polícia das décadas finais do século XIX e iniciais do século XX. A esse respeito, publicou-se em 1905 que "o Dr. Fuiz de Direito de Baturité, continua a ter como seu criado, o sentenciado fosé Raimundo, condemnado em 1903 por crime de morte" ${ }^{59}$. Não eram raras as denúncias nesse sentido. Afinal, combinavam-se discursos e práticas de coerção dos pobres ao trabalho e/ou de privação de sua liberdade em cadeias e asilos de mendicidade, ou, ainda, em "casas de família".

A ascensão de Olímpio Manoel dos Santos Vital à chefe da Secretaria de Polícia do Ceará se deu em 1886, dois anos após abolida a escravidão nessa província. Esse contexto marcou-se pelo aumento do rigor na vigilância aos pobres, incluindo os ex escravos. A abolição, do ponto de vista das elites senhoriais, suscitou certa insegurança no que tange ao arranjo de poder estabelecido na sociedade escravista. Este impasse foi patente no imaginário senhorial, a ponto de ser pertinente formular a seguinte questão: "Que philosophos estes! Que caturras! Alforriaes os negros... muito bem: Porém as surras quem as ha de levar, senhores, quem." "60. Noutras palavras, a pergunta era: como manter o paternalismo en-

58 Ibidem., p. 31.

${ }^{59}$ FBN - HDB -Jornal do Ceará, ano I, no 160, Fortaleza, Sexta-feira, 17/02/1905, p. 03. Disponível em: < http://memoria.bn.br/pdf/721247/per721247_1905_00160.pdf>. Acesso em: 15 nov. 2014.

${ }^{60}$ FBN - HDB - Libertador, ano I, no 02, Fortaleza, 15/01/1881, p. 10. Disponível em: <http:// memoria.bn.br/pdf/229865/per229865_1881_00002.pdf>. Acesso em: 06 fev. 2015. 
quanto engenharia de dominação social e, a partir daí, assegurar a manutenção do habitus senhorial?

\section{As reformas de Olímpio Manoel dos Santos Vital}

Olímpio Vital foi convidado pelo barão de Cotegipe para ocupar a chefatura de polícia no Ceará em 24 de agosto de 1886. Ficou 16 meses à frente da mesma, deixando o cargo em 24 de fevereiro de 1888, quando assumiu a presidência da província de Sergipe, indo posteriormente ocupar a liderança da secretaria de polícia da Bahia. Seu trabalho seria administrar a Secretaria de Polícia no sentido de que a realização de diversos serviços prestados na cidade passasse a depender de autorização policial, inclusive de registro dos seus praticantes através de matrícula junto à secretaria, sobretudo em se tratando de trabalhadores domésticos.

Diferentemente de antecessores, que se ocupavam prendendo pobres, Olímpio Vital teria atinado para a possibilidade de praticar uma política mais sofisticada, coerente com uma engenharia de poder e controle social na qual confinar indivíduos na Cadeia Pública não seria suficiente ou eficiente do ponto de vista do controle da população pobre. Para tanto, empreendeu, articuladamente, melhoramentos na cadeia pública, onde se achavam "reclusos mais de 200 infelizes", dando-lhe "condições hygienicas" 61 . De modo que, "aquellas medonhas e negras cellulas suffocantes de miasmas, estão agora completamente limpas e por assim dizer transformadas em quartos habitaveis", e mais, "a classificação dos presos segundo a idade, a moralidade, e condições, acha-se tambem agora convenientemente attendidas tanto quanto o permitte as condições do edificio; cessando os perigos de uma acumulação desordenada". Tais melhoramentos na estrutura do prédio da cadeia explicavam-se pelo sentido de tornar aqueles viventes confinados em corpos úteis, assim, "aproveitando utilmente o trabalho dos condemnados". Por esse expediente, "o digno e honrado magistrado consummou a obra

${ }^{61}$ FBN - HDB - Pedro II, ano 47, no 25, Fortaleza, Terça-feira, 29/03/1887, p. 01. Disponível em: <http://memoria.bn.br/pdf/216828/per216828_1887_00025.pdf>. Acesso em: 07 fev. 2016. 
de aterro e nivelamento de extensa rampa do lado do mar, afim de ser arborisada; para cujo lado ordenou a mudança da entrada geral das prisões". A mão de obra gratuita dos reclusos era revertida em favor do aprimoramento da própria estrutura em que estes mesmos seriam explorados na sua força de trabalho. Daí o relativo cuidado com as condições de salubridade da Cadeia e para evitar a lotação não calculada.

Os periódicos coevos às reformas de Olímpio Vital destacavam a sua capacidade de realizar mudanças "em todos os ramos do serviço publico, que cabem na esphera da administração policial"62, resultando em relevantes serviços "à causa publica". Também era este o teor de ofício da Câmara de Fortaleza, em fevereiro de 1888, felicitando-o por ser "incançavel em promover a exacta observancia da lei, a manutenção de todas as garantias cidadãs e o respeito ao poder publico, esforçando-se por tornar uma realidade a segurança de vida e propriedade, promettida pelas nossas leis". O mérito de Olímpio Vital, louvado pelas elites tanto conservadoras como liberais, estava no fato de que

(...) conseguiu restabelecer, em toda a latitude, a parte penal dos codigos que entende com os jogos prohibidos; melhorar o estado das prisões, tornando-as habitaveis e em condições de prehencher o seu fim social; facilitar as pesquisas da autoridade, no largo circulo de suas variadas attribuições, por meio d'um arrolamento exacto da população, com todas as indicações necessarias a trabalhos dessa ordem, e regular por si, ou auxiliar os poderes competentes a fazel-o, diversos outros serviços indespensaveis ás condições de existencia e desenvolvimento da sociedade. ${ }^{63}$

Faltou apenas citar, nesse excerto, o Código de Posturas para o serviço doméstico; pois, este também compôs o quadro de reformas administrativas que partiu da chefatura de polícia no pós abolição no

${ }^{62}$ FBN-HDB - Constituição, ano XXV, no 26, Fortaleza, Quarta-feira, 29/02/1888, p. 02. Disponível em: <http://memoria.bn.br/pdf/235334/per235334_1888_00026.pdf>. Acesso em: 07 fev. 2016.

${ }^{63}$ FBN - HDB - Constituição, ano XXV, n ${ }^{\circ}$ 26, Fortaleza, Quarta-feira, 29/02/1888, p. 02. Disponível em: <http://memoria.bn.br/pdf/235334/per235334_1888_00026.pdf>. Acesso em: 07 fev. 2016. 
Ceará, particularmente em Fortaleza. Ao encontro disso, seguiu a resposta que Olímpio Vital aduziu à Câmara municipal:

Eu não podia ser indifferente aos jogos prohibidos, que são um dos cancros mais terriveis da sociedade moderna, e devorador do pão da familia, da vida e da honra.Não podia tambem esquecer o melhoramento do estado das prisões, cuja inspecção me fôra confiada. A celula devia ser de castigo ao delinquente, mas nunca de sepultura para o vivo. $\mathrm{O}$ arrolamento da população era, alem de uma exigencia legal, uma necessidade palpitante depois da ultima secca que devastou a provincia. (...) Mas em tal serviço, como folgo de confessar, tirei grande partido da bôa indole e proverbial docilidade dos Cearenses, sempre dispostos às reformas úteis. ${ }^{64}$

É preciso abordar a confecção do censo da população fortalezense, para quantificar e conhecer a população a fim de melhor controlála, como o estabelecimento do código que regulamentou o trabalho doméstico, e previu a matrícula, na Secretaria de Polícia, dos criado(a)s e amas de leite, trabalhos estes com raízes na escravidão. Cabe ver que não foram coincidência as melhorias no sistema penitenciário da Cadeia Pública e medidas relativas à organização das relações de trabalho urbano em 1886/1887. Estes foram processos paralelos, combinados e complementares. O trabalho seria capaz de redimir e reabilitar não apenas o preso, mas igualmente a gente da cidade pobre e livre. As reformas realizadas pela Chefatura de Polícia - a melhoria na estrutura da Cadeia Pública, o combate aos jogos de azar, o arrolamento da população citadina e a regulamentação da contratação de criado(a)s de servir - compreendem um projeto de polícia preventiva, um paradigma de como o Estado lidaria com os pobres. Os libertos e pobres livres passaram a ser cativos no mundo do trabalho. Se, no campo, a regularização do mercado de trabalho começou a se dar por

${ }^{64}$ FBN-HDB - Constituição, ano XXV, no 26, Fortaleza, Quarta-feira, 29/02/1888, p. 02. Disponível em: <http://memoria.bn.br/pdf/235334/per235334_1888_00026.pdf>. Acesso em: 07 fev. 2016. 
volta de 1850, com o Projeto Alencar Araripe ${ }^{65}$, no meio citadino, esse processo é chave para entender a perpetuação do habitus senhorial e o fato de que as relações de trabalho foram tratadas no âmbito da vigilância e repressão policial ${ }^{66}$.

\section{Regulamentação do trabalho doméstico}

No final da década de 1880, diante da premência da abolição da escravidão, as províncias estavam providenciando estatísticas de sua população e estabelecendo posturas concernentes ao exercício de algumas profissões. No Ceará, tais medidas também foram implantadas. O projeto de regulação do contrato entre patrões e criado(a)s de servir em 1881 estava ligado ao contexto social proporcionado pelo término da grande seca de 1877-79, em que a maioria dos últimos escravos foi vendida para fora do Ceará, ficando nessa província forros e pobres ditos livres mas socialmente compreendidos em certa zona limiar entre a liberdade e a não liberdade, devido à imensa dependência que a pobreza lhes impingia. Esses (sobre)viventes convergiam para o serviço doméstico, que compreendia variada gama de funções e trabalhos dentro e fora das casas e sobrados da cidade.

Eurípedes Funes advertiu que, no pós-abolição, "no Ceará, em particular na cidade de Fortaleza, há um aumento considerável daqueles indivíduos sujeitos à condição de agregados e empregados domésticos"67. Em 1872, dos 1.183 escravos existentes na capital cearense, 816 (68,9\%) empregavam-se no trabalho doméstico. Esse contingente somado ao dos livres pobres completava o total de 5.585 pessoas; isto é, 26,1\% da população de Fortaleza, que era 21.372 habitantes ${ }^{68}$.

${ }^{65}$ MARIZ, Silviana Fernandes. Op. Cit. p. 76.

66 Ibidem. p. 79.

${ }^{67}$ FUNES, Eurípedes Antônio. Negros no Ceará. In: SOUSA, Simone de; GONÇALVES, Adelaide [et al]. Uma nova história do Ceará. 4. ed. Fortaleza: Edições Demócrito Rocha, 2007. p. 132.

${ }^{68}$ LINHARES, Juliana Magalhães. Entre a casa e a rua: trabalhadores pobres urbanos em Fortaleza (1871-1888). 2011. 182f. Dissertação (Mestrado em História Social), Universidade Federal do 
Por um lado, exigia-se perícia na realização dos afazeres domésticos, como lavar, passar, cozinhar. Por outro, injúria, ofensas feitas ao patrão ou a qualquer membro de sua família, bem como atos ilegais, imorais e lesivos aos bons costumes cometidos pelo criado serviriam de justa causa para fundamentar uma demissão. E aí residia boa parte do temor dos senhores de escravos e dos patrões; pois a vida social, num contexto de construção de espaços de sociabilidade burguesa, era feita não apenas de grandes eventos, mas da matéria comezinha do dia a dia que ora robustecia aparentemente o paternalismo, ora o corroía por dentro. Nesse sentido, embora existissem homens empregados nos trabalhos domésticos - não só como criados, mas em condições diversas a exemplo de agregados que poderiam ser parentes pobres ou crianças tuteladas -, imaginava-se que as mulheres fossem "mais afeitas à aparente leveza das tarefas do lar e supostamente mais inofensivas aos segredos familiares"69. Esse é o tema de obras como "Vitimas-algozes", do final da década 1860 e escrita por Joaquim Manuel de Macedo, e "O demônio familiar", comédia de José de Alencar escrita em meados de 1850, que mostravam os inconvenientes, desde a perspectiva senhorial, da escravidão doméstica no espaço urbano.

Os personagens criado(a)s, mucamas e amas de leite, no caso principalmente de Vítimas-algozes, seriam vítimas da sociedade escravista - como se os escravos não fossem capazes de negociarem, através do paternalismo com seus proprietários --, porém dotados de posição privilegiada para expor famílias a constrangimentos morais na sociedade. Lucinda é ali exemplo de mucama que corrompe Cândida, filha donzela do proprietário Florêncio da Silva. A mucama arma com Souvanel a fuga da sinhá-moça com este, francês que era o menos virtuoso partido para desposar Cândida, na Corte do país, em troca de viver com maior autonomia. Todavia, seus planos são desbaratados, mas não a tempo de evitar rebuliço e constrangimento no seio familiar.

Ceará, Fortaleza, 2011. p. 52.

${ }^{69}$ CUNHA, Maria Olívia Gomes da. Criadas para servir: domesticidade, intimidade e retribuição. In: ; GOMES, Flávio dos Santos (Orgs.). Op. Cit. p. 380. 
Em certa conferência da família de Florêncio da Silva e dona Leonídia, envolvendo, além destes, Liberato, deduziu-se que haveria entre Souvanel e Cândida uma "inteligência" maliciosa. Dessa conversa contemplativa, extraiu-se o seguinte trecho que é seminal para dar a ver a percepção senhorial do paternalismo e seus limites:

- Se temos inimigos de portas adentro! - exclamara Liberato.

- E quem são?

- Não se pergunta; são os escravos. Segurança e moralidade com a escravidão ninguém compreende.

- Mas eu trato paternalmente os meus escravos - observara Florêncio da Silva.

- Embora; nem é pai, nem eles são filhos; porque vossa mercê é senhor e eles são escravos: entre um e outros há um abismo cheio de ódio: escravos? Quem os educa?... São todos abandonados à perversão dos costumes: julga-se pai o que lhes dá pão, pano, e paciência de sobra; mas a alma e o coração desses desgraçados? Se lhes iluminassem as almas, adeus escravidão!... Nas trevas do espírito os corações escravos não podem abrir-se à virtude que é luz generosa, abrem-se à corrupção que tem embriaguez que olvida, noite que esconde gozos nefandos, consolação envenenada que é contraveneno dos martírios da escravidão. Guardamos em casa a peste, e pergunta-se donde vem o contágio?... ${ }^{70}$

Nessa passagem, evidencia-se a noção de que não haveria segurança, do ponto de vista moral, em manter escravos domésticos convivendo com os membros da família do senhor ou patrão. Por outro lado, os criados e criadas não eram prescindíveis para as elites urbanas e até para camadas médias, concernentes a famílias de profissionais liberais. Em casas ou sobrados, criadas e amas de leite, suspeitas pela cor e condição de terem costumes corruptos, desde o prisma dos valores senhoriais, eram muitas vezes alvo da libido diuturna dos senho-

${ }^{70}$ MACEDO, Joaquim Manuel de. As vítimas-algozes: quadros da escravidão. São Paulo: Martin Claret, 2010. p. 251. 
res e patrões. Desejos que estes haveriam de camuflar no interior do paternalismo, fio ideológico com o que se costurava sua dominação social, sob a qual poderia haver vária "noite que esconde gozos nefandos". A consolação de quem detém o poder de submeter o outro inclusive a objeto de prazer, de gozo, traz consigo um contraveneno da escravidão e da engenharia de dominação social que se queria perpetuar. Se for correto ler assim a passagem de Joaquim Manuel de Macedo sobre os limites do paternalismo, essa forma de poder própria das sociedades escravistas ensejava um veneno e seu contraveneno. O fio ideológico que costurava a dominação social dos senhores e patrões tinha uma face oposta, e o olhar interessado nesta pode enxergar como os dominados inventavam uma arte de resistência, face a face com o poder, negando ou afirmando o paternalismo quando lhes convinha.

Lucinda, nessa chave de leitura, seria uma mucama cativa que lançou mão de certa infrapolítica ${ }^{71}$ a fim de conseguir, nos limites do paternalismo, a liberdade ou a autonomia que fosse possível no bojo daquela sociedade escravista. Como evitar escândalos familiares sem prescindir do trabalho de criados de servir? Nos últimos anos da escravidão no Império, diversas províncias, inclusive a Corte, cuidaram em regular a alocação de trabalhadores em serviços domésticos. Tal procedimento consistia numa tentativa de o Estado conservar a distinção entre as relações havidas entre senhores, amos e patrões, de um lado, e criados nos espaços privados em relação aquelas havidas na espacialidade pública ${ }^{72}$. A casa evidencia-se cada vez mais enquanto lugar social onde se tecem relações sociais não horizontais, antes hie-

\footnotetext{
${ }^{71}$ A propósito do conceito de infrapolítica, ou política em escala cotidiana informada por certa arte da resistência própria dos dominados, ver: SCOTT, James C. A dominação e a arte da resistência: discursos ocultos. Tradução Pedro Serras Pereira. Lisboa: Livraria Letra Livre, s/d. p. 50.

${ }^{72}$ CUNHA, Olívia Maria Gomes da. Criadas para servir: domesticidade, intimidade e retribuição. In: ; GOMES, Flávio dos Santos (Orgs.). Op. Cit. p. 396.
} 
rárquicas que ensejam desigualdades de sorte diversa, como de gênero, étnicas e sociais ${ }^{73}$.

\section{O Código de Posturas Para o Serviço Doméstico de 1887}

As posturas reguladoras do serviço doméstico, de 1887, concebidas num contexto em que moral e trabalho se articulavam, buscavam moralizar, conforme interesse senhorial, as relações entre patrões e criados, pois se tratava de ratificar, conforme se escasseava o elemento servil, o âmbito doméstico das famílias como locus da coerção e exercício do poder que outrora se dava abertamente no domínio público. Conforme Olívia Maria Gomes da Cunha ${ }^{74}$, analisando a concepção do projeto de regulação do serviço doméstico na Corte, em 1889, "o projeto invadia um território de relações domésticas e privativas. À guisa de proteger as famílias, seus propugnadores se lançavam na defesa dos patrões, vítimas das "classes perigosas". Desenvolve-se, aqui, um entendimento diverso deste.

As posturas normalizadoras da contratação de criados de servir consistem num modo de reforçar prerrogativas dos amos e patrões, embora tivessem dispositivos favoráveis aos criados, como a demissão apenas mediante aviso prévio dos patrões àqueles. Mesmo aqui, esse dispositivo atendia a interesses e conveniências dos locadores dos serviços domésticos. Isso fica patente em publicação n'O Diario, de 1892, em que se lê: "estão no dominio de todos as grandes difficuldades e insuperaveis embaraços que nos causam dia a dia o systema porque entre nós é feito o serviço domestico"75; e segue, "não há mãe de familia que de um momento para outro não seja atirada aos encargos do serviço culinario, porque a sua criada lh'a deixou sem aviso prévio e sem causa justa".

${ }^{73}$ Ibidem. p. 381.

${ }^{74}$ CUNHA, Olívia Maria Gomes da. Criadas para servir: domesticidade, intimidade e retribuição. In: CUNHA, Olívia Maria Gomes da; GOMES, Flávio dos Santos (orgs.). Quase-cidadão: histórias e antropologias da pós-emancipação no Brasil. Rio de Janeiro: Editora FGV, 2007. p. 398.

${ }^{75}$ FBN - HDB - O Diario, ano I, no 5, Fortaleza, 20/05/1892, p.01. Disponível em: <http:// memoria.bn.br/pdf/4494/per4494_1892_00005.pdf>. Acesso em: 08 fev. 2017. 
Não se trata de oferecer proteção às famílias que empregassem em sua propriedade trabalhadores em serviços domésticos. Antes, cuidava-se de reforçar a desigualdade assente entre patrões e criados no âmbito da domesticidade privada, onde os contratos eram desrespeitados ou sequer concebidos, na medida em que havia um grande contingente de homens e mulheres realizando trabalhos domésticos sem qualquer registro na Secretaria de Polícia. Na prática, as normas criadas pelo Chefe de Polícia Olímpio dos Santos Vital, e abalizadas pela Câmara Municipal de Fortaleza, endossavam regras não escritas, isto é, não tornadas direito positivo, mas sabidas pelo costume, que diziam respeito ao que patrões podiam em relação aos seus contratados e, por outro lado, o que estes não podiam em relação aos primeiros.

As regras de alocação de criados e amas de leite concorreram ainda no sentido de endossar discursos que atribuíam à família, de indivíduos livres e proprietários, certa moralidade. Haveria, conforme Olívia Gomes, espécie de economia moral doméstica que marcava o papel de cada membro que coabitava a casa, o espaço da domesticidade $^{76}$. Isso era condizente com certo apelo à boa virtude dos criados nos anúncios, sobretudo, à moralidade das criadas e amas de leite, de quem cuja nutrição dos filhos recém-nascidos dos patrões e patroas dependia. As criadas que apresentassem sinais de gravidez durante o contrato seriam também, por justa causa (art. $12^{\circ} \S$ único do Código de Posturas Para o Serviço Doméstico), despedidas.

Aliás, eram comuns anúncios de aluguel de criadas com destaque para o critério de não estarem grávidas ou sequer possuírem filhos; como neste, de 1873: "aluga-se uma escrava donzella, de 18 annos, para o serviço interior de alguma casa honesta, sob condição de não sahir á rua. 134-Á Rua Amelia - 134"77; ou neste outro, de 1890: "Ama de Leite. Precisa-se de

${ }^{76}$ CUNHA, Olívia Maria Gomes da. Criadas para servir: domesticidade, intimidade e retribuição. In: ; GOMES, Flávio dos Santos (Orgs.). Op. Cit. p. 395.

${ }^{77}$ FBN - HDB - O Cearense, ano XXVII, no 02, Fortaleza, Domingo, 05/01/1873, p. 01. Disponível em: <http://memoria.bn.br/pdf/709506/per709506_1873_00002.pdf>. Acesso em: 16 out. 14. 
uma sadia e sem filho, á praça do Marquez de Herval - 26"78. O que, aliás, exigia que a mulher, ama de leite, abrisse mão de amamentar seu próprio filho que sobreviveria, diante desta situação, por sorte ou teimosia.

A escrava que se tornava mãe normalmente era separada do filho, mesmo depois de 1871, quando a Lei 2.040 libertou o ventre das mulheres cativas. Embora a prática não tenha cessado, a lei marcou, na relação senhor e escravo, a conquista de um direito das mulheres em condição servil. O filho vendido e a mãe lactante aproveitada para amamentar os pequenos senhores, recém-nascidos. Havia senhores que estipulavam, no anúncio de aluguel de criadas, a condição de estas ainda serem virgens; como se vê n'O Cearense, de 1872, "ALUGA-SE UMA ESCRAVA DONZELLA, de 18 annos, para o serviço interior de alguma casa honesta sob condicção de não sahir à rua" ${ }^{79}$. Nessa condição, a escrava não teria mobilidade nenhuma, praticamente, servindo aos senhores contratantes 24 horas por dia, todos os dias. Conforme interpretação de alguns, se alugassem os serviços de uma mulher já mãe e solteira e com a possibilidade de sair à rua, para fazer pequenas compras, por exemplo, isso poderia atrair a vigilância de costumes que então se praticava. Na sonoridade das ruas de Fortaleza, ouvia-se impropérios, intrigas, notícias diversas sobre a cidade e sua gente, enfim, conversas de toda sorte. "A linguagem da rua era provocativamente sexual e racial" 80 . Uma criada, cozinheira ou ama de leite ou ama seca, que saísse à rua poderia ser confundida com meretriz, muito embora houvesse "mulheres públicas" que frequentassem lugares como o mercado de carne que pretendiam passar por criadas de servir, devidamente empregadas em "casa de família"81.

\footnotetext{
${ }^{78}$ FBN - HDB - O Estado do Ceará, ano I, n ${ }^{\circ}$ 20, Fortaleza, Terça-feira, 12/08/1890, p. 03. Disponível em: <http://memoria.bn.br/pdf/225746/per225746_1890_00020.pdf>. Acesso em: 02 ago. 14.

${ }^{79}$ FBN - HDB - O Cearense, ano XXV, n 5, Fortaleza, Quarta-feira, 17/01/1872, p. 03. Disponível em: <http://memoria.bn.br/pdf/709506/per709506_1872_00005.pdf>. Acesso em: 14/10/2015.

${ }^{80}$ GRAHAM, Sandra Lauderdale. Proteção e obediência: criadas e seus patrões no Rio de Janeiro, 1860-1910. Tradução de Viviana Bosi. São Paulo: Companhia das Letras, 1992. p. 60.

${ }^{81}$ GRAHAM, Sandra Lauderdale. Loc. Cit.
} 
A influência do burburinho da rua na casa dos patrões era algo que se temia e se procurava controlar. Aliás, como asseverou Hannah Arendt, "o único modo eficaz de garantir a escuridão do que deve ser escondido da luz da publicidade é a propriedade privada, um lugar possuído privadamente para se esconder" 82 , no qual criadas escravas ou mesmo livres eram mantidas no cativeiro da casa de família. Os criados que realizavam serviços internos e externos faziam a mediação desses espaços. Poderia ocorrer de um criado ou criada sentir-se coagido ou ser convencido a tomar alguma atitude que prejudicasse certo patrão ou patroa.

As mulheres sabiam bem como lidar com a vivência na rua. Boa parte da população dos arrabaldes de Fortaleza era composta por mulheres retirantes que, superada a seca de 1877-79, não retornaram para o interior da Província. No entanto, havia a noção de que as mulheres eram mais susceptíveis a assédios diversos. Daí porque, quando se precisava no aviso de aluguel o sexo da pessoa a ser contratada, acrescentava-se a exigência de boa conduta, como a nota a seguir permite conhecer: "precisa-se de uma mulher, para o serviço de uma casa de família, e que tenha boa conducta; quem julgar-se n'estas condicções, dirïa-se a rua da Palma $n^{\circ} 76^{\prime \prime 83 . ~}$

O trabalho nos serviços domésticos era bastante cansativo; não havia hora certa para começar nem para concluir-se a rotina de trabalhos. Várias situações afeitas à convivência das pessoas em cada casa indicariam o momento de começar o trabalho, assim como de encerrá-lo. O que faziam os criados relativamente à manutenção de determinada casa não era visto como uma forma de trabalho socialmente produtivo, sobretudo quando se tratava de um(a) criado(a) ou agregado(a) que houvesse sido, no sentido estrito do termo, criado(a) junto(a) a certa família para ali servir e receber o de comer e beber e, muito pouco ainda, o de vestir.

\footnotetext{
${ }^{82}$ ARENDT, Hannah. A condição humana. Tradução Roberto Raposo. 11. ed. Rio de Janeiro: Forense Universitária, 2010. p. 87.

${ }^{83}$ FBN-HDB - O Cearense, ano XXV, n 135, Fortaleza, Quarta-feira, 22/11/1871, p. 04. Disponível em: <http://memoria.bn.br/pdf/709506/per709506_1871_00135.pdf>. Acesso em: 10 set. 2015.
} 
Algumas pessoas listadas no Arrolamento da População de Fortaleza de 1887 haviam sido escravas e mantinham-se cativas nas residências de seus senhores. Os dados desse recenseamento não deixam identificar criado(a)s que até 1884 foram oficialmente escravo(a)s de seus respectivos patrões. Mas o Livro de Matrícula de Criados de Servir informa a existência de Eugenia Joaquina da Conceição, criada de João Luiz Rangel, que a respeito desta anotou na matrícula respectiva tratar-se de sua "ex-escrava, [que] continua a residir em minha casa como creada, gratuitamente, por tempo indeterminado" $"$. Do mesmo modo, boa parte dos trabalhadores em serviços domésticos que não nascera em condição servil submetia-se à relação de trabalho em que nada recebia de salário. A criada Thereza Maria da Conceição estabeleceu contrato com Manoel Fernandes Araújo, em agosto de 1887, para serviço doméstico gratuito, recebendo "em paga comida e roupa, por [tempo] indeterminado"85. Entre ex escravo(a)s e criado(a)s nascido(a)s livres, mas cativo(a)s nos serviços domésticos, havia em comum amiúde o fato de nada receberem por seu trabalho em termos de salário. Constituindose, assim, o espaço privado doméstico, entre famílias de diferentes camadas sociais, num lugar de reprodução e conservação de relações de poder que eram óbices à conquista da liberdade civil pelos criado(a)s e amas de leite forros e pobres livres. Um lugar, portanto, de reprodução de certo habitus senhorial.

A contratação de criado(a)s e amas de leite seguiu sem regulamentação durante quase toda a década de 1880, coube à Secretaria de Polícia, em abril de 1887, empreender legislação que definisse os critérios da contratação de trabalhadores para serviços domésticos na Província, especialmente, na sua capital. Algumas províncias, como São Paulo e Bahia, já tinham criado normas referentes à locação de criado(a)s e amas de leite. Em artigo do Libertador, em que foi sauda-

${ }^{84}$ APEC - Governo da Província - Secretaria de Polícia. Livro de Matrícula de Criados de Servir, 1887, f. 09, p. 15.

${ }^{85}$ APEC - Governo da Província - Secretaria de Polícia. Livro de Matrícula de Criados de Servir, 1887, f. 12. 
do como inteligente e laborioso, Olímpio Vital defendeu tal medida argumentando que se tratava de "imperiosa necessidade" 86 e que "nesta provincia, em que tal necessidade mais se faz sentir, principalmente nesta capital”, a opinião pública teria se manifestado favoravelmente à adoção de regras para tal locação.

À polícia não caberia tão somente a repressão aos pobres, indivíduos inúteis e não laboriosos que perambulavam pela cidade e seus arrabaldes. Uma das atribuições dessa corporação seria a prevenção de crimes por parte daqueles tendenciosos a práticas marginais. Daí a importância de a polícia agir no sentido de lhes obrigar a procurarem "uma occupação util e honesta" evitaria de recorrer a meios "morosos" de "repressão da vadiagem". Conforme ressalvou João Brígido, um comerciante de escravos e agente de criado(a)s, "pela baratesa dos salarios, a lavoura do Ceará se fazia quasi exclusivamente com braços livres. Os escravos occupavão-se em serviços domesticos, não havendo outra criadagem" ${ }^{88}$. Os serviços domésticos agregavam tanto trabalhadores(as) escravos como forros e livres, havendo pouca ou nenhuma distinção de tratamento em relação à sua condição civil. Os criados e criadas livres podiam até sofrer certa depreciação alusivamente aos cativos, na medida em que não representavam para os senhores capital investido. Muito embora houvesse aluguéis de criado(a) $\mathrm{s}$ ditos livres a terceiros.

Nesse sentido, Vital concebia a regulação dos critérios de locação de criados de servir como medida intrinsicamente ligada ao processo de arrolamento da população de Fortaleza, que visava a quantificar e identificar os viventes dessa cidade; tornando, com isso, a estatística

${ }^{86}$ FBN-HDB-Libertador, ano VII, no 116, Fortaleza, Quarta-feira, 27/04/1887, p. 02. Disponível em: <http://memoria.bn.br/pdf/229865/per229865_1887_000116.pdf>. Acesso em: 21 jun. 2014.

${ }^{87}$ FBN - HDB - Libertador, ano VII, no 116, Fortaleza, Quarta-feira, 27/04/1887, p. 02. Disponível em: <http://memoria.bn.br/pdf/229865/per229865_1887_000116.pdf>. Acesso em: 21 jun. 2014.

${ }^{88}$ BRIGIDO, João. Ephemerides do Ceará. Revista Trimensal do Instituto do Ceará, ano XIV, $3^{\circ}$ e $4^{\circ}$ Trimestres, de 1900, Tomo XIV, Fortaleza, 1900, p. 220. Disponível em: <http://memoria. bn.br/pdf/144843/per144843_1900_00003-00004.pdf>. Acesso em: 09 fev. 2017. 
(no sentido de statistik, "ciência de Estado") ${ }^{89}$ uma ferramenta fundamental para sofisticar a racionalidade da administração do Estado, em escala provincial - mas não só, posto que esse processo se dava paulatinamente em todo o Império. Este, grosso modo, o sentido e a justificação política da estatística policial. O sentido de polícia no século XVIII, ensina Robert Darnton, similarmente também apontava para uma "administração racional" 90 . Nesse sentido, a estatística constituiu uma ferramenta para policiar os citadinos, sobretudo os pobres - muitos dos quais trabalhadores em serviços domésticos.

Através da Polícia, erigida em instituição produtora de conhecimentos sobre a realidade social visando a governabilidade, a administração provincial iniciou processo de representação do mundo social, elencando assim categorias fixas e pretensamente objetivas de classificação como estado civil, profissão, nacionalidade, instrução, idade, etc., que capturariam a fisionomia do contingente populacional em dado momento. A estatística constituía uma técnica, um saber, que se tornou instrumento de uma arte de governar, cada vez mais interessada na população, na escala dos indivíduos por um lado; e na da família, por outro.

Olímpio Vital, visando a dotar o poder público de conhecimentos objetivos, embora eivados de preconceitos e subjetividades, coordenou a realização do levantamento dos moradores da capital cearense não sem antes deixar marcada a vinculação orgânica entre as duas ações principais de sua gestão à frente da Secretaria de Polícia por escrito. Assim, num ofício enviado para à Câmara Municipal, aduziu que

Crear-se, pois, na Secretaria de policia um registro, onde se inscrevão os que tiverem ou tomarem a profissão de serviço doméstico e se tomem as dividas

${ }^{89}$ CAMARGO, Alexandre de Paiva Rio. Mensuração racial e campo estatístico nos censos brasileiros (1872-1940): uma abordagem convergente. Boletim do Museu Paraense Emílio Goeldi. Ciência Humanas, Belém, v. 4, n. 3, 2. semestre 2009. p. 363.

${ }^{90}$ DARNTON, Robert. Os dentes falsos de George Washington: um guia não convencional para o século XVIII. TraduçãoJosé Geraldo Couto. São Paulo: Companhia das Letras, 2005. p. 110-111. 
notas sobre o procedimento delles e contractos que celebrem, é uma necessidade não só para o auxilio da estatistica a que a mesma policia é obrigada a proceder, como tambem um elemento de convicção contra os que infringirem as disposições legaes conservando-se - vadios -, e portanto um meio de evitar e prevenir taes delictos.

Convencido da importancia do alludido registro e resolvido á maior solicitude na repressão dos crimes policiaes relativos a falta de occupação util e honesta, não posso furtar-me ao dever de representar a essa camara sobre a conveniencia da adopção de posturas referentes a este assumpto, a exemplo do que já se fez em S. Paulo desde o anno passado e ultimamente na Bahia. ${ }^{11}$

O projeto submetido à Câmara por Olímpio Vital, contendo 12 artigos e que valeria para Fortaleza, definia, já no primeiro artigo, que o criado(a) deveria ser pessoa de condição livre, que, mediante salário, tomasse a ocupação de moço de hotel, casa de pasto ou hospedaria, bem como de cozinheiro, copeiro, lacaio, cocheiro, hortelão ou jardineiro, engomadeira, costureira e ama de leite ou seca. Para crianças e mulheres, havia a obrigação de apresentarem autorização de pai ou tutor e, no caso destas, do marido, desde que estivessem casadas e vivendo em companhia do mesmo $\left(\operatorname{art} .1^{\circ} \S 2^{\circ}\right)$. O que de certo modo constituía um instrumento legal para ratificar o poder de pais/tutores, condizente com os valores patriarcais arraigados na sociedade, sobre filhos e menores dependentes e sobre mulheres, no tocante à capacidade de alugarem seu trabalho.

O locador do serviço obrigava-se a possuir caderneta, fornecida pela Câmara Municipal mediante pagamento da quantia de 600 mil réis $\left(\operatorname{art.~} 1^{\circ} \S 3^{\circ}\right)$, na qual deveria constar certificado de antigo patrão e o contrato atual do serviço em que estivesse empregado, autenticada pelo órgão administrador da polícia $\left(\right.$ art. $1^{\circ} \S 4^{\circ}$ ) e matricular-se em livro de registro na Secretaria de Polícia $\left(\operatorname{art.} 1^{\circ} \S 1^{\circ}\right)$. Havia também as-

${ }^{91}$ FBN-HDB - Libertador, ano VII, no 116, Fortaleza, Quarta-feira, 27/04/1887, p. 02. Disponível em: <http://memoria.bn.br/pdf/229865/per229865_1887_000116.pdf>. Acesso em: 21 jun. 2014. 
sentes em tal projeto dispositivos legais para coibir o(a) trabalhador(a) de abandonar o trabalho. Este(a), quando contratado(a) por tempo indeterminado, deveria observar e cumprir o aviso prévio de oito dias ao patrão se pretendesse deixar o respectivo serviço $\left(\right.$ art. $\left.1^{\circ} \S 6^{\circ}\right)$. Por seu lado, o patrão, igualmente, tinha de respeitar o aviso prévio de mesmo número de dias, em situação de contrato por tempo indeterminado, e as causas consideradas justas para demitir seu criado ou criada, bem como ama de leite, sendo a multa para o infrator de $20 \$ 000$ réis ou quatro dias de prisão, e o dobro disto para reincidentes (art. $2^{\circ} \S 4^{\circ}$ ). Pode-se entender que isso dava uma segurança relativa para o criado, no entanto, foi mais um artifício legal para beneficiar os patrões.

As punições eram severas para as mulheres que se davam ao aluguel como amas de leite. Isso se depreende do artigo $4^{\circ}$ que estipula que "a ama de leite, alem da pena a que está sujeita pela infracção dos $\$ \oint 1^{\circ} 2^{\circ}$ $3^{\circ} 4^{\circ} 5^{\circ}$ e $7^{\circ}$ do Art. $1^{\circ}$ incorrerá na multa de 30:000 ou 8 dias de prisão e o dobro nas reincidências" $" 92$. As justas causas para despedida de amas de leite tinham agravantes como a falta ou "corrupção" de seu leite, gravidez e falta de cuidado com a criança lactente (art. $\left.7^{\circ}\right)$. Mas, a essas causas, somavam-se todas aquelas previstas no artigo $5^{\circ}$, que dispunha acerca das hipóteses permitidas para demissão sumária dos criados de servir, em geral. Nesse item, estabelecia-se que

Art. $5^{\circ}$ - Para os effeitos das presentes posturas são justas causas para ser despedido o criado ou creada, antes de findo o praso do contracto: $1^{\mathrm{a}}$ enfermidade de que prive a pessoa de prestar o serviço para que ajustou-se; $2^{\circ}$ embriaguez habitual; $3^{\circ}$ infidelidades nas contas; $4^{\circ}$ impericia notória para desempenhar o serviço contractado; $5^{\circ}$ recusa de prestal-o; $6^{\circ}$ calumnia, injuria, offensa e falta de respeito devido, tanto contra o patrão como contra pessôa de sua familia; $7^{\circ}$ pratica de actos contrarios ás leis e bons costumes, $8^{\circ}$ manifestação de gravidez na creada reputada virgem, ou na casada que estiver ausente de seu marido. ${ }^{93}$

${ }^{92}$ FBN-HDB - Libertador, ano VII, n ${ }^{\circ}$ 117, Fortaleza, Quinta-feira, 28/04/1887, p. 02. Disponível em: <http://memoria.bn.br/pdf/229865/per229865_1887_000117.pdf>. Acesso em: 21 jun. 2014.

${ }^{93}$ FBN-HDB - Libertador, ano VII, no 117, Fortaleza, Quinta-feira, 28/04/1887, p. 02. Disponível em: <http://memoria.bn.br/pdf/229865/per229865_1887_000117.pdf>. Acesso em: 21 jun. 2014. 
Quando a aludida postura parecia favorecer aos criados, em geral, não deixava de lhes impor armadilhas ou dispositivos que, na prática, não seriam usufruídos. Imagina-se que um criado(a) fosse, diante do acometimento do patrão ou da patroa por qualquer mal, constrangido socialmente - e este tipo de norma prescindia de ser escrita, pois já enraizada no imaginário social e senhorial - a continuar servindo ao mesmo ou a mesma. Isso também vale para o não pagamento de salários ou atraso destes. Em geral, os trabalhadores empregados no serviço doméstico não tinham sua situação nesse contexto de trabalho avalizada por aquisição de vencimentos. A relação tendia a ser tratada, não obstante o esforço do Estado em regular a contratação de trabalhadores para serviços domésticos, por dentro dos meandros da intimidade doméstica, onde se misturavam complexamente afetos diversos, deferências, expectativas de reconhecimento e obediência. Tudo isso, enfim, dando o (dis)sabor do paternalismo, por meio do qual tanto criados(as) quanto patrões reconfiguravam simbólica e concretamente as relações de sociabilidade e poder havidas no interior daquele território social, que nas últimas décadas do XIX, fora concebido como epicentro de uma engenharia de controle, a saber, casa. Aqui, coabitavam, em residências de famílias abastadas ou apenas remediadas, patrões e criados, às vezes coincidindo serem ex senhores e ex escravos ou, se não, criado(a)s livres, porém nascidos para servir. E era nessa proximidade de relações que se testavam os limites do paternalismo como ideologia de sustentação da dominação social e de reprodução da escravidão no âmbito da cultura, isto é, do habitus senhorial.

\section{Considerações Finais}

Até aqui o leitor pode já haver se questionado sobre o que tem a ver temas que costumam ser tratados e desenvolvidos em áreas diversas da historiografia. Ao se emaranhar considerações sobre o tráfico interprovincial, as campanhas abolicionistas e as tentativas de regulação do trabalho doméstico, corre-se o risco de nada acrescentar acerca de objetos tão contemplados em inúmeras pesquisas concebidas a par- 
tir do escopo da história social da migração, do trabalho, da escravidão e da abolição. Por outro lado, reconhecendo-se as eventuais lacunas e carência de análise mais detida e aprofundada acerca de certos pontos da narrativa que se desenvolveu neste texto - até mesmo em respeito aos limites de sua natureza -, tal abordagem pode desvelar certos meandros e conexões do processo de libertação dos escravos no Ceará, em conexão com a organização de categorias profissionais no mundo do trabalho urbano, que abrem possibilidades outras de análise e leituras dessa história.

Conquanto esta se trate de uma pesquisa sobre a história do serviço doméstico no contexto do processo de libertação dos escravos, em Fortaleza, sabe-se que nos últimos anos de vigência da escravidão no Império tentou-se em diferentes províncias, como em São Paulo, Bahia e mesmo na Corte, regulamentar os serviços domésticos. Esses processos não foram realidades históricas desconexas. Analisando-se a cidade de Fortaleza, soube-se que destacados comerciantes de escravos tornaram-se abolicionistas, integrando inclusive agremiações com esse fim, a exemplo de Joaquim da Cunha Freire, Luiz Ribeiro da Cunha e Virgínia Salgado. Num certo sentido, esses traficantes articularam-se de tal modo a definirem os termos nos quais o processo de libertação dos cativos no Geará se daria.

Enriquecidos com o tráfico de gente no circuito interprovincial, tais comerciantes investiam também na compra de imóveis em Fortaleza e em seus arrabaldes, a fim de garantirem renda proveniente de aluguel dessas propriedades. Deparou-se com anúncios em jornais que ofertavam esses imóveis para aluguel destacando haver escravos para os serviços domésticos. Também era comum encontrar anúncios desses mesmos traficantes oferecendo para aluguel criados(as) e amas de leite, sobretudo na medida em que se tornou mais oneroso o comércio de escravos entre as províncias, com o advento da década de 1880. Em geral, as mulheres destinavam-se a alocação em residências para serviços domésticos, sendo os homens preferidos para o trabalho braçal nas fazendas do Sul do País. O que não se quer, com isso, sugerir que se tratasse o trabalho nas casas de algo menos extenuante. 
Diante dessas conexões, vê-se que o trabalho doméstico tem suas raízes históricas fincadas na escravidão. Quando se tentou, em 1881, regular a contratação de criados de servir, Joaquim da Cunha Freire presidia a Câmara Municipal e a Junta Classificadora de Escravos, da capital cearense, cuja finalidade era destinar os recursos advindos do Fundo de Emancipação, criado pela Lei 2.040, de 1871. Além disso, ao se estudar o Arrolamento da População de Fortaleza, de 1887, promovido pelo Chefe de Polícia Olímpio Manoel dos Santos Vital, o mesmo que criou o Código de Posturas Para o Serviço Doméstico, datado do mesmo ano, cruzando-o com as informações do Livro de Matrícula de Griados de Servir encontra-se criados ex escravos trabalhando na casa de seu antigo proprietário sem haver estabelecido contrato e sem receber salário algum, apenas tendo como paga o que comer, beber e onde se abrigar das noites.

Portanto, a abolição extinguiu a condição jurídica de ser servil, no entanto, socialmente proporcionou certa reengenharia de dominação social, tendo-se a casa como epicentro dessa domesticação social. Tratava-se de manter sob novas circunstâncias elementos do escravismo naquela sociedade. Reajustar o paternalismo como ideologia de dominação e o habitus senhorial como prática de poder. Sempre contestado, das mais diversas formas, desde as mais altissonantes às mais silenciosas e dissimuladas, o poder não se exerce plenamente. Sua prática deixa brechas. E a arte de resistir às diversas formas de dominação social não cessa de inventar, face a face com o poder, suas condições de possibilidade no chão histórico. Essa dialética não se fecha ou se encerra, assim como a história.

\section{Bibliografia}

ALBUQUERQUE, Wlamyra R. de. O jogo da dissimulação: abolição e cidadania negra no Brasil. São Paulo: Companhia das Letras, 2009. 
ARENDT, Hannah. A condição humana. Tradução Roberto Raposo. 11. ed. Rio de Janeiro: Forense Universitária, 2010.

BOBBIO, Norberto. Liberalismo e democracia. 6. ed. Tradução Marco Aurélio Nogueira. São Paulo: Brasiliense, 2000.

BOURDIEU, Pierre. O poder simbólico. 8. ed. Tradução Fernando Tomaz. Rio de Janeiro: Bertrand Brasil, 2005.

CAMARGO, Alexandre de Paiva Rio. Mensuração racial e campo estatístico nos censos brasileiros (1872-1940): uma abordagem convergente. Boletim do Museu Paraense Emílio Goeldi. Ciência Humanas, Belém, v. 4, n. 3, p. 361-385, 2. semestre 2009.

CHALHOUB, Sidney. A força da escravidão: ilegalidade e costume no Brasil oitocentista. São Paulo, Companhia das Letras, 2012.

CHALHOUB, Sidney. Precariedade estrutural: o problema da liberdade no Brasil escravista (século XIX). História Social, Campinas, SP, nº 19, pp. 19-32, 2010.

CHALHOUB, Sidney. Visões da liberdade: uma história das últimas décadas da escravidão na corte. São Paulo: Companhia das Letras, 1990.

CUNHA, Olívia Maria Gomes da. Criadas para servir: domesticidade, intimidade e retribuição. In: ; GOMES, Flávio dos Santos (Orgs.). Quase-cidadão: histórias e antropologias da pós-emancipação no Brasil. Rio de Janeiro: Editora FGV, 2007. p. 376-417.

DARNTON, Robert. Os dentes falsos de George Washington: um guia não convencional para o século XVIII. Tradução José Geraldo Couto. São Paulo: Companhia das Letras, 2005.

FERNANDES, Yaco. Notícia do povo cearense. 2. ed. Fortaleza: CASA DE JOSÉ DE ALENGAR/UFG, 1998.

FUNES, Eurípedes Antônio. Negros no Geará. In: SOUSA, Simone de; GONÇALVES, Adelaide [et al]. Uma nova história do Ceará. 4. ed. Fortaleza: Edições Demócrito Rocha, 2007.

GIRÃO, Raimundo. A Abolição no Ceará. 3. ed. Fortaleza: Secretaria de Cultura e Desporto, 1984.

GRAHAM, Sandra Lauderdale. Proteção e obediência: criadas e seus patrões no Rio de Janeiro, 1860-1910. Tradução de Viviana Bosi. São Paulo: Companhia das Letras, 1992.

GONÇALVES, Adelaide. "Uma fábrica de homens utilizáveis: sobre escola 
e instrução pública para os pobres no Ceará". In: RIOS, Kênia Sousa; FURTADO FILHO, João Ernani. Em tempo: História, memória, Educação. Fortaleza: Imprensa Universitária, 2008. p. 81-110.

HOLLOWAY, Thomas H. Polícia no Rio de Janeiro: repressão e resistência numa cidade do século XIX. Tradução de Francisco de Castro Azevedo. Rio de Janeiro: Editora Fundação Getúlio Vargas, 1997.

JUNIOR, A. de Paula Ramos. Comentário ao código criminal brasileiro. Rio de Janeiro: Carioca, 1875.

LAPA, José do Amaral. Os excluídos: contribuição à história da pobreza no Brasil (1850-1930). Campinas, SP: Editora da UNICAMP, 2008.

LAPA, José Roberto do Amaral. A cidade: os cantos e os antros: Campinas 1850-1900. São Paulo, SP: Editora da USP; Campinas, SP: Editora da UNICAMP, 2008.

LIMA, Henrique Espada. Sob o domínio da precariedade: escravidão e os significados da liberdade de trabalho no século XIX. Topoi, Rio de Janeiro, v. 6, n 11 , p. 289-326, 2. semestre 2005.

LINHARES, Juliana Magalhães. Entre a casa e a rua: trabalhadores pobres urbanos em Fortaleza (1871-1888). 2011. 182f. Dissertação (Mestrado em História Social), Universidade Federal do Ceará, Fortaleza, 2011.

MACEDO, Joaquim Manuel de. As vítimas-algozes: quadros da escravidão. São Paulo: Martin Claret, 2010.

MARIZ, Silviana Fernandes. Oficina de Satanás: a Cadeia Pública de Fortaleza (1850-1889). 2004. 386f. Dissertação (Mestrado). Universidade Federal do Ceará, Fortaleza, 2004.

MATTOSO, Kátia de Queirós. O filho da escrava (em torno da Lei do Ventre Livre). Revista Brasileira de História, São Paulo, v.8, n 16, p. 37-55, 1. semestre 1988 .

MENESES, Antonio Bezerra de. O Ceará e os cearenses. Revista da Academia Cearense, Tomo V, Typographia Studart, Fortaleza, p. 146-207, 1900.

MOURA, Clóvis. Dicionário da escravidão negra no Brasil. São Paulo: Editora da Universidade de São Paulo, 2004.

NEDER, Gizlene. Discurso jurídico e ordem burguesa no Brasil. Porto Alegre: Sergio Antonio Fabris Editor, 1995.

PESAVENTO, Sandra Jatahy. Trabalho livre e ordem burguesa: Rio Grande do Sul - 1870-1900. Revista de História, São Paulo, Universidade de São 
Paulo, n. 120, p. 135-151, 1989.

PINHEIRO, Marlene Soares. A travessia do avesso: sob o signo do carnaval. São Paulo: Annablume, 1995.

SAFFIOTI, Heleieth Iara Bongiovanni. Emprego doméstico e capitalismo. Petrópolis: Vozes, 1978.

SCHIMMELPFENG, Gisela Paschen. A mulher e a abolição. Fortaleza: Secretaria de Cultura e Desporto, 1984.

SCHWARCZ, Lilia Moritz. Dos males da dádiva: sobre as ambigüidades no processo de Abolição brasileira. In: CUNHA, Olívia Maria Gomes da; GOMES, Flávio dos Santos (Orgs.). Quase-cidadão: histórias e antropologias da pós-emancipação no Brasil. Rio de Janeiro: Editora FGV, 2007. p. $23-54$.

SCOTT, James C. A dominação e a arte da resistência: discursos ocultos. Tradução Pedro Serras Pereira. Lisboa: Livraria Letra Livre, s/d.

STAROBINSKI, Jean. As máscaras da civilização: ensaios. Tradução de Maria Lúcia Machado. São Paulo: Companhia das Letras, 2001.

TELES, Lorena Feres da Silva. Libertas entre sobrados: mulheres negras e trabalho doméstico em São Paulo (1880-1920). São Paulo: Alameda, 2014.

Recebido: 02/03/2016 - Aprovado: 11/09/2017 